\title{
Iconografía de La Dormición de la Virgen en los siglos X-XII. Análisis a partir de sus fuentes legendarias
}

\author{
José María SAlvador GonzÁlez \\ Universidad Complutense de Madrid \\ Departamento de Historia del Arte I (Medieval) \\ jmsalvad@ghis.ucm.es
}

Recibido: 6 de julio de 2011

Aprobado: 7 de noviembre de 2011

\section{RESUMEN}

El presente artículo busca poner de relieve si y en qué medida la iconografía medieval de la Dormición de la Virgen refleja los detalles centrales o periféricos de tres textos apócrifos, cuyos autores son el Pseudo Juan el Teólogo, el arzobispo Juan de Tesalónica y el Pseudo José de Arimatea. Para ello, pondremos en relación directa los pormenores narrativos de esas tres leyendas apócrifas con los personajes, gestos, acciones y circunstancias plasmados en las representaciones bizantinas y occidentales más sobresalientes de este motivo iconográfico durante los siglos X-XII.

Palabras clave: Arte medieval, Iconografía, Dormición de María, Koimesis, apócrifos, siglos X-XII.

\section{Iconography of The Dormition of the Virgin in the 10th to 12th Centuries. An Analysis from its Legendary Sources}

\begin{abstract}
This article aims to highlight if and to what extent the medieval iconography of the Dormition of the Virgin reflects the central or peripheral details of three apocryphal texts, written by the Pseudo John the Theologian, the archbishop John of Thessalonica and the Pseudo Joseph of Arimathea. Thus, we will put in direct relation the narrative details of these three apocryphal legends with the persons, the gestures, the actions, and the circumstances shaped in the most outstanding Byzantine and western representations of this iconographic subject during the 10th-12th centuries.
\end{abstract}

Keywords: Medieval Art, Iconography, Dormition of the Virgin, Koimesis, Apocryphal Writings, 10th12th Centuries.

\section{SUMARIO}

Fuentes literarias de La Dormición de María. Imágenes de La Dormición De María en los siglos X-XII La Koimesis en el arte bizantino a fines de la alta Edad Media. La Dormición bizantina en los siglos X-XI. La Koimesis bizantina en el siglo XII. La Dormición de María en el arte occidental de los siglos X-XII. La Dormición en la miniatura occidental. La Dormición de María en el arte monumental de Occidente. Análisis iconográfico de las Dormiciones de los siglos X-XII. Conclusiones. Fuentes. Bibliografía. 


\section{Fuentes literarias de La Dormición de María}

Como es bien sabido, no subsisten datos históricos ni referencias bíblicas que permitan reconstruir las circunstancias precisas de la muerte y la sepultura de la Virgen María. A falta de semejantes documentos canónicos, entre las comunidades cristianas de Oriente surgieron pronto de manera apócrifa varias leyendas piadosas, de presunta tradición apostólica, que trataron de escribir la "historia oficial" del tránsito de la madre del Mesías. ${ }^{1}$ Convencidos de la condición sobrehumana de la Theotókos, los anónimos autores de esas leyendas apócrifas no dudaron en imaginar que el fallecimiento, los funerales, la sepultura e incluso la eventual resurrección de la Virgen estuvieron signados por una abundante serie de prodigiosos fenómenos e increíbles milagros.

Tal como lo enuncia el propio título de nuestro artículo, nos restringimos aquí al estudio de las fuentes legendarias de la Dormición de María, prescindiendo ahora del análisis de sus numerosas y ricas fuentes patrísticas y teológicas, las cuales estudiamos en otro trabajo. ${ }^{2}$ Ahora bien, dentro del inmenso acervo de escritos apócrifos del Antiguo y el Nuevo Testamento, nos interesan para los fines de este artículo sólo los apócrifos asuncionistas, es decir, los directamente referidos a la muerte y asunción de María. ${ }^{3}$ Entre éstos, elegimos los tres que, por su antigüedad y su originalidad, se destacan muy por encima de otros apócrifos asuncionistas más tardíos y, a todas luces, derivados de aquéllos. Esos tres apócrifos primigenios son: el Tratado de San Juan el Teólogo sobre la dormición de la Santa Madre de Dios (llamado Libro de San Juan Evangelista o el Pseudo Juan el Teólogo, ${ }_{4}^{4}$ cuya redacción se estima del siglo IV o antes) ${ }^{5}$; Dormición de Nuestra Señora, Madre de Dios y siempre Virgen María, escrita por Juan, arzobispo de Tesalónica (conocido como Libro de Juan de Tesalónica, ${ }^{6}$

${ }^{1}$ Casi todos los eruditos fechan los primeros apócrifos asuncionistas en el siglo IV. Sin embargo, algunos expertos sostienen que las primeras versiones apócrifas se remontan hasta el siglo II, período en el que habría sido escrito el relato del presunto hereje Leucio, e incluso el propio texto del Ps. Juan el Teólogo.

${ }^{2}$ Véase el texto "La Asunción de María. De la leyenda al dogma", el cual constituye el capítulo 5 del libro de nuestra autoría Ancilla et Regina. Aproximaciones a la iconografia mariana en la Edad Media, Saarbrücken, Editorial Académica Española, 2011 (en prensa).

${ }^{3}$ Para una visión de conjunto de los apócrifos neotestamentarios y, en especial, de los asuncionistas, en traducción española, cf. Aurelio de SANTOS OtERo, Los evangelios apócrifos, Salamanca: La Editorial Católica, Col. Biblioteca de Autores Cristianos, 148, 2006, 705 p. Para otros apócrifos asuncionistas de tradición árabe o copta, cf. Gonzalo ArANDA PÉREz, Dormición de la Virgen. Relatos de la tradición copta, Madrid: Editorial Ciudad Nueva/Fundación San Justino, Col. Apócrifos Cristianos, 2, 1995, 324 p.; y Pilar GonzÁlez Casado, La dormición de la Virgen. Cinco relatos árabes, Madrid: Trotta, 2002, $218 \mathrm{p}$.

${ }^{4}$ Pseudo Juan el Teólogo, Tratado de San Juan el Teólogo sobre la dormición de la Santa Madre de Dios. Asumimos el texto bilingüe (griego / español) de este apócrifo de la edición que de él aporta Aurelio de Santos Otero (2006: 576-600). En adelante citaremos los pasajes de este apócrifo con el nombre de su autor, con el capítulo de su texto en números romanos, seguido de la página de la edición de Santos Otero en numeración arábiga: por ejemplo, Ps. Juan el Teólogo, XII: 581.

5 Cf. Santos Otero 2006: 574.

6 Juan de Tesalónica, Dormición de Nuestra Señora, Madre de Dios y siempre Virgen María. Tomamos aquí el texto bilingüe (griego / español) de este apócrifo según la edición que de él brinda 
fechable a inicios del s. VII) 7 y De transitu Beatae Mariae Virginis (auctore PseudoJosepho ab Arimathea) ${ }^{8}$ refundición algo tardía de los dos escritos precedentes.

De entrada, creemos necesario sintetizar el contenido esencial de ese trío de textos legendarios. Obviando una serie de curaciones milagrosas, puniciones divinas y otras incidencias fabulosas descritas por uno u otro de esos tres apócrifos asuncionistas, podríamos resumir así los elementos medulares en los que todos ellos, pese a diversas variantes, coinciden en mayor o menor medida. Mientras ora en el sepulcro de Jesús, o mientras se halla en su casa de Belén, según dos de esas leyendas, María recibe el anuncio de su próxima muerte por boca del arcángel Gabriel ${ }^{9}$ (o de un simple y anónimo ángel), quien le entrega además para su sepelio una palma traída del paraíso. ${ }^{10}$ Recibido el anuncio de su inminente fallecimiento, la Virgen regresa con presteza a su casa en Belén con las tres doncellas que le sirven, y allí pide a Dios que le envíe a Juan el Evangelista y a los demás apóstoles, con el fin de volver a verlos, anunciarles su tránsito y despedirse de ellos. ${ }^{11}$ Llegado desde Éfeso sobre una nube, ${ }^{12}$ Juan dialoga con María, quien le comenta la promesa hecha por su hijo Jesús, al asegurarle que, en el trance de su muerte, vendría Él con los ángeles para recibir su alma y llevarla al cielo. ${ }^{13}$ Tras una potente voz diciendo "Amén", el Espíritu Santo convoca a todos los apóstoles, vivos y muertos, haciéndoles venir sobre nubes luminosas desde los más remotos confines de la tierra hasta Belén, para asistir a María en su óbito. Por virtud del Espíritu Santo los apóstoles llegan todos a la vez a la casa de María, con gran regocijo de ésta. ${ }^{14}$ Luego cada apóstol, incluyendo Pablo y Tomás (contra lo descrito por el Ps. José de Arimatea), ${ }^{15}$ narra a la Virgen desde dónde y de qué manera llegó a Belén sobre una nube resplandeciente. ${ }^{16}$ Mientras la Theotókos reza con los apóstoles en su hogar de Belén, se produce un fuerte trueno, se oye una gran voz y

Santos Otero (2006: 605-639). En adelante citaremos los pasajes de este apócrifo con el nombre de su autor, con el capítulo de su texto en números romanos, seguido de la página de la edición de Santos Otero en numeración arábiga.

7 Cf. SAntos Otero 2006: 646.

8 Pseudo José de Arimatea, De transitu Beatae Mariae Virginis (auctore Pseudo-Josepho ab Arimathea). Utilizamos aquí el texto bilingüe (latín / español) que de este apócrifo ofrece SANTOS OTERo (2006: 640-653). En adelante citaremos los pasajes de este apócrifo con el nombre de su autor, con el capítulo de su texto en números romanos, seguido de la página de la edición de Santos Otero en numeración arábiga.

9 Ps. Juan el Teólogo, I-III: 576-577. Juan de Tesalónica, III-IV: 609-612. Según éste último autor, quien anuncia su muerte a María es "el gran ángel", y lo hace en casa de ésta, antes de salir, por indicación del propio ángel, hacia el Monte de los Olivos. (Ibid.).

10 Ps. Juan el Teólogo, III: 577; Juan de Tesalónica, III: 609-611; Ps. José de Arimatea, IV: 643.

${ }^{11}$ Ps. Juan el Teólogo, IV-V: 577-578; Juan de Tesalónica, III-IV: 609-612. Ps. José de Arimatea, V: 643-644.

12 Ps. Juan el Teólogo, VI-X: 578-580; Juan de Tesalónica, III: 609-611; Ps. José de Arimatea, VI: 644.

13 Ps. Juan el Teólogo, VI-X: 578-580; Juan de Tesalónica, III: 609-611.

${ }_{14}$ Ps. Juan el Teólogo, XI-XII: 580-581; Juan de Tesalónica, VII: 618-620; Ps. José de Arimatea, VII-VIII: 645.

15 Ps. José de Arimatea, VII: 645.

${ }^{16}$ Ps. Juan el Teólogo, XVI-XXV: 583-587. 
un ejército de ángeles y serafines rodea la casa de María, ${ }^{17}$ para gran sorpresa de los betlemitas y de muchos habitantes de Jerusalén, mientras se producen numerosas curaciones milagrosas. ${ }^{18}$ Decididos a atacar a la Virgen y a los discípulos, los sacerdotes judíos, al verse impedidos de hacerlo por un castigo divino, solicitan al gobernador romano enviar un quiliarco con sus huestes contra la madre de Jesús y los apóstoles. Sin embargo, éstos, al momento de transportar a su Señora yacente en el lecho, son conducidos sobre una nube por el Espíritu Santo desde Belén hasta la casa de María en Jerusalén, a salvo de los ataques de los judíos. ${ }^{19} \mathrm{El}$ domingo, momentos después de pedir María a los apóstoles disponerse a orar y a quemar incienso, ${ }^{20}$ Jesucristo, al conjuro de un gran trueno y bajo los efluvios de un intenso perfume, se presenta entre resplandores en la casa de su madre, escoltado por multitud de ángeles, querubines y serafines, todos ellos cantando himnos celestiales. ${ }^{21}$ Luego de reconfortarla, Jesús comunica a su madre que ese mismo día su cuerpo sería trasladado al paraíso y su alma subiría al cielo. ${ }^{22}$ Bendecida por Jesús, y tras bendecir ella misma a los discípulos, María se pone en oración y pide a su hijo conceder mediante su intercesión todas las gracias solicitadas por quienes la invoquen como mediadora. ${ }^{23} \mathrm{Al}$ mandato del Mesías, solicitando a Pedro iniciar la salmodia, la Virgen se levanta de su lecho, bendice a cada apóstol y exhala su último suspiro en medio de una luz inefable y un perfume exquisito. ${ }^{24}$ Jesús entonces recibe el alma de su madre ${ }^{25} \mathrm{y}$, envolviéndola en unos velos de indescriptible resplandor, se la entrega al arcángel Miguel para que la traslade al paraíso. ${ }^{26}$ Los apóstoles entonces, ante la orden del Redentor de llevar el cuerpo de María a un sepulcro nuevo a las afueras de la ciudad, depositan su cadáver en el ataúd y se lo llevan donde había ordenado el Maestro. ${ }^{27}$ Mientras conducen en cortejo fúnebre el cuerpo de la Theotókos, un judío llamado Jefonías (o un pontífice anónimo, según Juan de Tesalónica, o cierto Rubén, según el Ps. José de Arimatea) quiere profanarlo derribando el féretro, pero un ángel le corta ambos brazos, que quedan colgados del ataúd. ${ }^{28}$ Pero, tras proclamar, a instancias de Pedro, las maravillas de Cristo y María, el profanador recibe en premio el milagro de la recuperación de sus

17 Ps. Juan el Teólogo, XXVI-XXVIII: 587-588; Ps. José de Arimatea, XI: 647

18 Ps. Juan el Teólogo, XXVI-XXVIII: 587-588.

19 Ps. Juan el Teólogo, XXIX-XXXVI: 588-592; Ps. José de Arimatea, XIII: 648. El Ps. José de Arimatea sitúa la amenaza de ataque de los judíos después de la muerte de María. (Ibid.).

${ }^{20}$ Ps. Juan el Teólogo, XXXVII-XXXIX: 592-593; Juan de Tesalónica, VI: 615-618.

${ }^{21}$ Ps. Juan el Teólogo, XXXVII-XXXIX: 592-593; Juan de Tesalónica, XII: 630-632; Ps. José de ARIMATEA, XI: 647.

22 Ps. Juan el Teólogo, XXXVII-XXXIX: 592-593.

${ }^{23}$ Ps. Juan el TeÓlogo, XL-XLIV: 594-596.

${ }^{24}$ Ps. Juan el TeÓlogo, XLI- XLV: 595-597.

25 Ps. Juan el Teólogo, XliV: 596; Ps. José de Arimatea, XI: 647.

26 Juan de Tesalónica, XII: 630-632.

27 Ps. Juan el Teólogo, Xli- XlV: 595-597; Juan de Tesalónica, XII: 630-632; Ps. José De ArimateA, XIV: 648-649.

28 Ps. Juan el TeÓlogo, XlVI- XlVII: 597-598; Juan de Tesalónica, XIII: 632-637; Ps. José De Arimatea, XIV: 648-649. Según el Ps. José de Arimatea, los brazos del profanador se quedaron secos sobre el féretro, sin haber sido cortados. 
brazos y su conversión al cristianismo. ${ }^{29}$ Concluido este milagro, los apóstoles trasladan el cuerpo de la Virgen en el ataúd al huerto de Getsemaní y lo depositan en un sepulcro sin estrenar, del que se desprende un delicioso perfume. Durante tres días se oyen cánticos de ángeles invisibles. Mas, al cesar tales cánticos el tercer día, los apóstoles constatan que el cuerpo de María ha sido conducido al paraíso, ${ }^{30}$ después de lo cual ven a muchos santos, profetas y ángeles venir a venerar la reliquia de la Virgen, entre himnos angélicos y en medio de un fragante aroma. ${ }^{31}$ El Ps. José de Arimatea, añade el fabuloso episodio según el cual el incrédulo apóstol Tomás, ausente durante el sepelio de la madre de Dios, y viendo a ésta en el momento de su asunción al cielo mientras él mismo venía con retraso sobre una nube desde la India, le pide el cíngulo con que la ciñeron los apóstoles al amortajarla. ${ }^{32}$ Ese cíngulo mariano servirá a Tomás de signo testimonial para probar ante los discípulos la resurrección inmediata y la asunción corporal de María al cielo. ${ }^{33}$ Por último, otras tantas nubes devuelven a cada apóstol al lugar de donde habían sido arrebatados antes de la dormición de María. ${ }^{34}$

Aun suscitando la suspicacia y el rechazo de numerosos Padres de la Iglesia, entre ellos, San Jerónimo, el contenido esencial de esos tres escritos apócrifos fue adoptado sin excesivas reservas por algunos otros Padres, Doctores y teólogos medievales, sin dejar de ser conscientes de la inverosimilitud de la mayoría de sus episodios y pormenores. Sobre tan legendarios cimientos narrativos construyeron ellos una sólida estructura de digresiones poéticas, reflexiones devocionales, comentarios catequéticos y exégesis doctrinales, con el propósito de suscitar la crédula piedad de los fieles y hacer más asequibles los inaprehensibles enigmas de los dogmas. Se solidifica así a lo largo de la Edad Media un corpus mariológico híbrido, en el que se mezclan en inextricable urdimbre fantasía y realidad, leyenda e historia, razón y fe. Nada, quizá, ilustra mejor el reciclaje de los datos centrales de esos cuentos apócrifos asuncionistas por parte de los Doctores de la Iglesia que la síntesis que San Juan Damasceno (675749) hace suya, tras confesar haberla recibido de Juvenal, arzobispo de Jerusalén:

Tomando la palabra, Juvenal respondió: "En la santa Escritura inspirada por Dios no se cuenta lo que pasó en la muerte de la santa Theotókos María, pero nosotros nos apoyamos en una tradición antigua y muy verídica de que en el momento de su gloriosa dormición, todos los santos Apóstoles, que recorrían la tierra para la salvación de las naciones, fueron reunidos en un instante a través de los aires en Jerusalén. Cuando estuvieron cerca de ella, unos ángeles se les aparecieron en una visión, y un divino concierto de las potencias superiores se dejó oír. Y así, en una gloria divina y celestial, la Virgen entregó en las manos de Dios su santa alma de una manera inefable. En cuanto a su cuerpo, receptáculo de la divinidad, fue transportado y enterrado, en medio de cantos de los ángeles y de los Apóstoles, y depuesto en un ataúd en Getsemaní, donde durante

29 Ps. Juan el TeÓlogo, XLVI- XLVII: 597-598; Juan de Tesalónica, XIII: 632-637; Ps. José De Arimatea, XV: 649.

30 Ps. Juan el Teólogo, XlViII-L: 598-600; Juan de Tesalónica, XIV: 637-639; Ps. José de ArimateA, XVI: 649.

31 Ps. Juan el Teólogo, XLVIII-L: 598-600.

32 Ps. José de Arimatea, XVII: 649-650.

33 Ps. José de Arimatea, XVIII-XXI: 650-652.

34 Ps. José de Arimatea, XXII: 652. 
tres días perseveró sin descanso el canto de los coros angélicos. Después del tercer día, habiendo cesado esos cantos, los Apóstoles presentes abrieron el ataúd a petición de Tomás, que era el único que había estado lejos de ellos, y que, venido el tercer día, quiso venerar el cuerpo que había llevado a Dios. Pero su cuerpo digno de toda alabanza, no pudieron encontrarlo de ninguna manera; no encontraron sino los vestidos funerarios puestos allí, de los que emanaba un perfume inefable que los penetraba, y ellos cerraron el ataúd. Presos de admiración ante el prodigio misterioso, he aquí lo único que pudieron concluir: aquel que en su propia persona se dignó encarnarse en ella y hacerse hombre, Dios el Verbo, el Señor de la gloria, y que guardó intacta la virginidad de su Madre después de su nacimiento, había querido aún, tras su partida de aquí abajo, honrar su cuerpo virginal e inmaculado con el privilegio de la incorruptibilidad; y con una traslación antes de la resurrección común y universal. Estando presentes entonces los Apóstoles, el santo apóstol Timoteo, primer obispo de Éfeso, y Dionisio Areopagita, como lo testimonia él mismo, el gran Dionisio, en sus discursos dirigidos a dicho apóstol Timoteo, a propósito del bienaventurado Hieroteo, también presente entonces... ${ }^{35}$

Desde otra perspectiva, con un lenguaje más poético y sutil, Jacobo de Sarug (c. 451-521) había ya confirmado también el aprovechamiento de los apócrifos por los teólogos medievales, al poner en evidencia su propio caso: en una homilía para la fiesta de la Dormición de María, sintetiza así el hacendoso trajinar de las potencias celestiales y de los terrenales apóstoles en el tránsito y el sepelio de la madre del Hijo de Dios, en consonancia con lo expuesto por los apócrifos:

Ad Matrem usque huius Iesu Christi, Filii Dei, mors venit, ut ipsa eius calicem gustaret.

Imperavit Dominus excelsis Virtutibus et supernis, flammantibusque legionibus, igneis Cherubim.

Descenderunt angelorum turmae secundum cohortes: alta voce cecinerunt gloriosa iubila.

(...) Stat electorum duodecim chorus Apostolorum, qui virginale corpus benedictae Mariae sepelit. ${ }^{36}$

Tras esta primera aproximación a las fuentes literarias apócrifas del tránsito de la Virgen, hora es ya de estudiar las correspondientes representaciones artísticas.

\section{Imágenes de La Dormición de María en los siglos X-XII}

La fiesta litúrgica de la Dormición de María y su iconografía correspondiente se fundan en sus inicios no sólo en esas leyendas apócrifas ya referidas, sino también en

35 Saint Jean Damascène, Deuxième discours sur l'illustre Dormition de la Toute Sainte et toujours Vierge Marie, 18. En Saint Jean Damascène, Homélies sur la Nativité et la Dormition (Texte grec, introduction, traduction et notes par Pierre Voulet), Paris: Les Éditions du Cerf, Coll. Sources Chrétiennes, 1961, p. 173.

${ }^{36}$ Jacobo de Sarug (c. 451-521), Homilia de sancta Dei Matris Dormitione et sepultura. En: Sergio Alvarez Campos (comp.), Corpus Marianum Patristicum, vol. V, Burgos, Aldecoa, 1981, p. 96 
numerosos sermones, himnos, comentarios y disquisiciones dogmáticas de algunos Padres y Doctores de la Iglesia, teólogos, filósofos, homiletas, himnógrafos, liturgistas y otros escritores de la Iglesia oriental, como San Modesto de Jerusalén († 634), ${ }^{37}$ San Andrés de Creta $(† 720),{ }^{38}$ San Germán de Constantinopla $(† 733),{ }^{39}$ el arzobispo Juan de Tesalónica (s. VII), ${ }^{40}$ San Juan Damasceno $(675-749){ }^{41}$ y San Teodoro Studita (759-826). ${ }^{42}$ Esos aportes greco-orientales sobre la muerte de la Virgen serán luego complementados con otras similares contribuciones doctrinales por parte de algunos escritores sacros de la Iglesia occidental.

Inspirada en tales fuentes literarias, surge luego en el ámbito bizantino la iconografía de la Koimesis o Dormición de María, que, algún tiempo después, será adoptada y readaptada en el ámbito occidental. Resulta, sin embargo, imposible precisar la fecha exacta -o, al menos, el siglo - en que comenzaron a representarse las primeras Koimesis. Habida cuenta de la masiva destrucción de imágenes en el Imperio Bizantino durante la crisis iconoclasta (726-843), no sería impensable conjeturar que haya habido alguna representación de la Dormición de la Virgen antes del siglo X. Sin embargo, semejante conjetura no puede ser confirmada de manera fehaciente con los documentos que tenemos a nuestro alcance. Lo único cierto es que, según el criterio unánime de los expertos, las primeras imágenes que se conservan de la Koimesis datan del siglo X. Tal certeza justifica nuestra decisión metodológica de iniciar el período a investigar precisamente en el siglo X. Por otra parte, extendemos dicho período hasta el siglo XII, fecha que signa de modo claro una nueva época artística y cultural: la Baja Edad Media.

Nuestro propósito en la presente disertación es intentar mostrar si y en qué medida la iconografía medieval de la Dormición de la Virgen refleja los detalles centrales o periféricos de los tres apócrifos asuncionistas recién mencionados. Al restringirnos ahora a la iconografía de la Koimesis durante los siglos X-XII, y tras descartar la imposible pretensión de estudiar de modo exhaustivo todas las imágenes subsistentes sobre el tema en el lapso elegido, analizaremos aquí algunas de las más sobresalientes representaciones de este motivo mariano en el arte bizantino y occidental durante las tres centurias bajo escrutinio. Los criterios utilizados para elegir las obras de arte a analizar obedecen, sobre todo, a la originalidad de su propuesta narrativa y a la calidad de su ejecución estilístico-formal, según el criterio casi unánime de los expertos. Ambos criterios inciden en la notable dispersión cronológica y geográfico-cultural de las distintas obras elegidas, dispersión que se hace particularmente apreciable en los diversos territorios sujetos a la influencia política o cultural de Bizancio.

37 San Modesto de Jerusalén, Encomium in dormitionem Deiparae, PG 86, 3288 ss.

38 SAn ANDrés de CReta, In dormitionem Deiparae, PG 97, 1053 ss; y 1081 ss.

39 SAn Germán de Constantinopla, In sanctam Dei Genitricis dormitionem, PG 98, 345 ss.

40 De este escritor, véase el libro apócrifo que mencionaremos más adelante, muchos de cuyos detalles asumiremos en los análisis iconográficos que propondremos en nuestro artículo.

${ }^{41}$ Véase el ya citado libro bilingüe (griego/francés) SAINT JeAn Damascėne, Homélies sur la Nativité et la Dormition (edición de Pierre Voulet), 1961.

42 San Teodoro Studita, Laudes in dormitionem Deiparae, PG 99, 719 ss. 


\subsection{La Koimesis en el arte bizantino a fines de la Alta Edad Media}

\subsubsection{La Dormición bizantina en los siglos X-XI}

Cuatro iconos bizantinos en marfil o esteatita del siglo X con imágenes de la Koimesis, y otras dos piezas análogas del siglo XI, presentan idéntica estructura compositiva y los mismos elementos descriptivos del tema bajo escrutinio: los cuatro primeros se conservan en el Museum of Fine Arts de Houston, ${ }^{43}$ (Fig. 1) en el Kunsthistorisches Museum de Viena, ${ }^{44}$ (Fig.2) en el Metropolitan Museum of Art de Nueva York, ${ }^{45}$ (Fig.3) y en la Bayerische Staatsbibliothek de Munich ${ }^{46}$ (Fig. 4) (éste último, casi idéntico al del Metropolitan neoyorquino); los dos ejemplares del siglo XI son el icono en marfil del Museo de Cluny en París ${ }^{47}$ y el casi idéntico panel de un políptico en marfil de las doce Grandes Fiestas, perteneciente al Museo de Darmstadt (Alemania). ${ }^{48}$

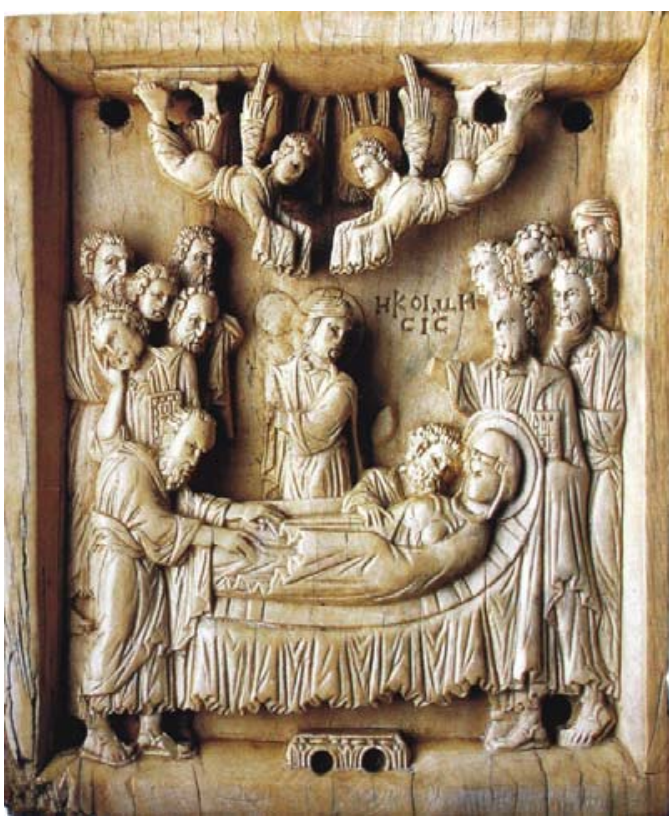

Fig. 1. Icono con Koimesis, marfil, mediados s. X, Museum of Fine Arts, Houston.

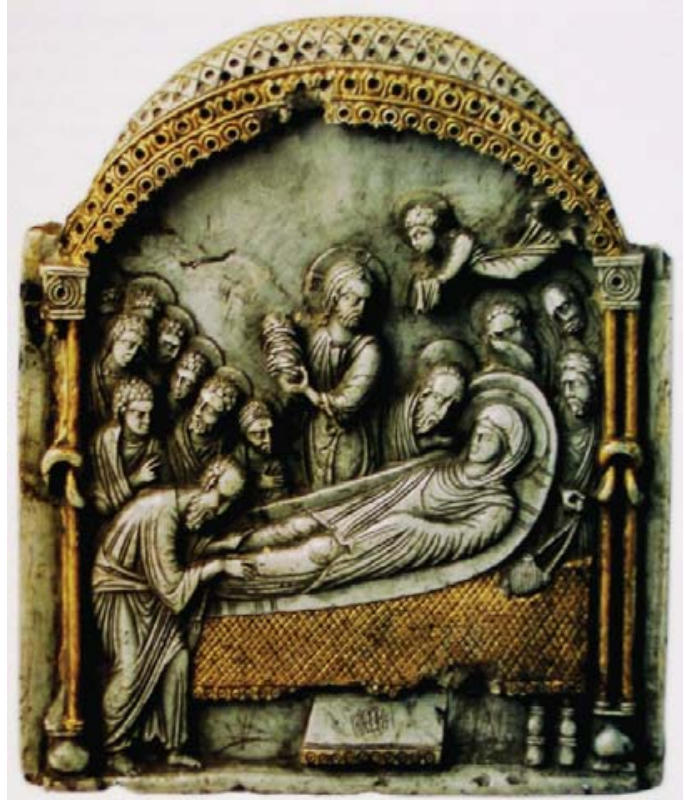

Fig. 2. Icono con Koimesis, esteatita, $2^{\mathrm{a}}$ mitad s. X. Kunsthistorisches Museum, Viena.

${ }^{43}$ Icon with the Koimesis, Byzantine (Constantinople), mediados del siglo X, marfil, 10,6 x 8,7 x 1,4 $\mathrm{cm}$. The Museum of Fine Arts, Houston, Texas. Repr. en color en Evans, Wixom (eds.) 1997: 149-150 (análisis), $\mathrm{n}^{\circ} 95$.

${ }^{44}$ Icon with the Koimesis, Byzantine, $2^{\mathrm{a}}$ mitad del s. X, esteatita dorada, 13 x 11,2 x 1,7 cm. Kunsthistorisches Museum, Viena, Repr, en color en Evans, Wixom (eds.) 1997: 155-156 (análisis), no 102.

${ }^{45}$ Icon with the Koimesis, Byzantine (Constantinople), fines del s. X, marfil, 18,7 x 14,9 cm. The Metropolitan Museum of Art, Nueva York. Repr. en color en Evans, WiXOM (eds.) 1997: 154-155 nº 101.

${ }^{46}$ Icono con Koimesis, Constantinopla (?), último cuarto del s. X, marfil. Bayerische Staatsbibliothek, Munich. Repr. en Schiller 1980, Band 4,2: 348, fig. 587.

${ }^{47}$ Icono con Koimesis, bizantino, s. XI, marfil, Museo de Cluny, París. Repr. en Toscano 1960, vol. 2: 177, fig. 145. Giuseppe Toscano (Ibid.) fecha esta pieza eboraria en el siglo XII.

${ }^{48}$ Repr. en Coche de la Ferté 1981: 425, fig. 539, y p. 456, nº 539. 
Debido al escasísimo espacio disponible, teniendo en cuenta las minúsculas dimensiones de las placas de marfil o esteatita, ${ }^{49}$ la composición se simplifica al máximo en esas seis piezas suntuarias. Por tal motivo, en todas ellas sólo se asumen los personajes y episodios esenciales: la Virgen yacente en posición horizontal sobre la cama, cuya cabecera (salvo en los ejemplares gemelos de Cluny y Darmstadt) se orienta hacia el lado derecho; los apóstoles, reunidos a ambos lados en dos grupos simétricos, el primero en torno a Pedro, situado en la cabecera del lecho, mientras el otro grupo de discípulos se recoge en la banda opuesta, dirigido por Pablo, quien siempre abraza los pies de María; irguiéndose en el centro de la composición, a modo de fulcro equilibrador, Jesús recibe en sus brazos el alma de su madre, representada como un recién nacido fajado, y la eleva hacia su derecha, a la izquierda del cuadro (salvo en los iconos de Cluny y Darmstadt, en los que lo hace en el sentido contrario), para entregársela a un par de ángeles (excepto en el ejemplar de Viena, con un solo ángel), que revolotean por encima del Mesías, con sus manos cubiertas por velos rituales, en señal de respeto para no tocar directamente el alma santa de María. A excepción del lujoso lecho mortuorio, de ricas telas bordadas o recamadas, y una peana en el centro del borde inferior del panel, no hay en estos seis preciosos iconos ningún otro mobiliario o elemento escenográfico.

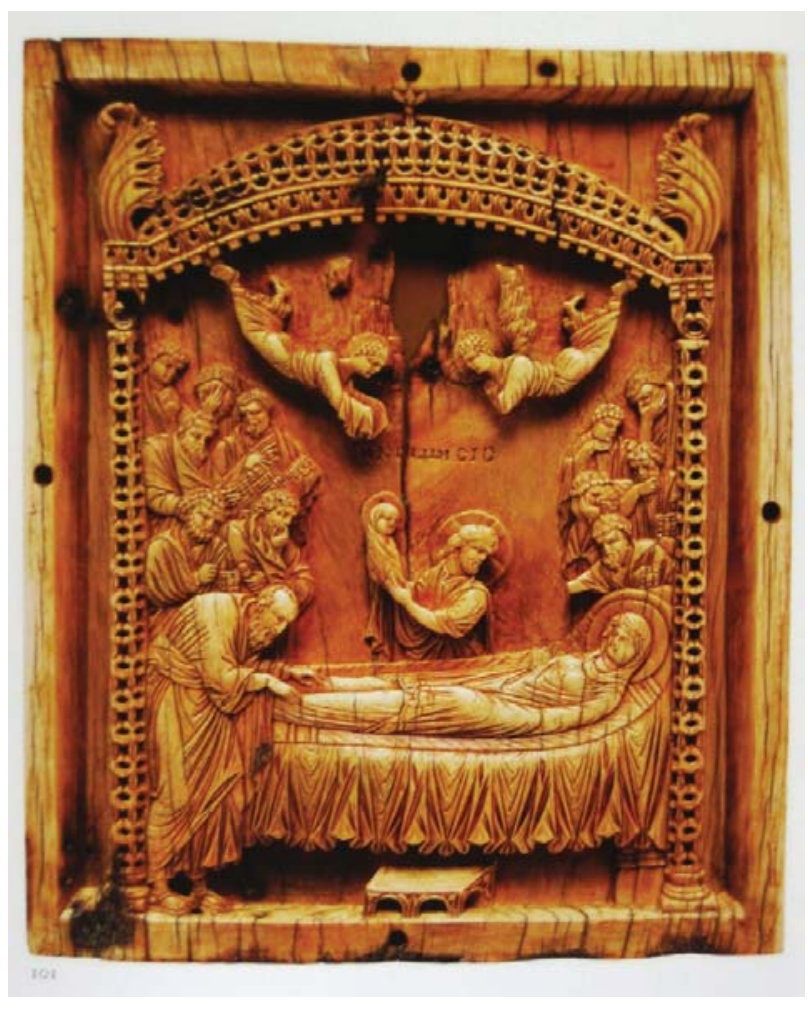

Fig. 3. Icono con Koimesis, marfil, fines s. X, Metropolitan Museum, New York.

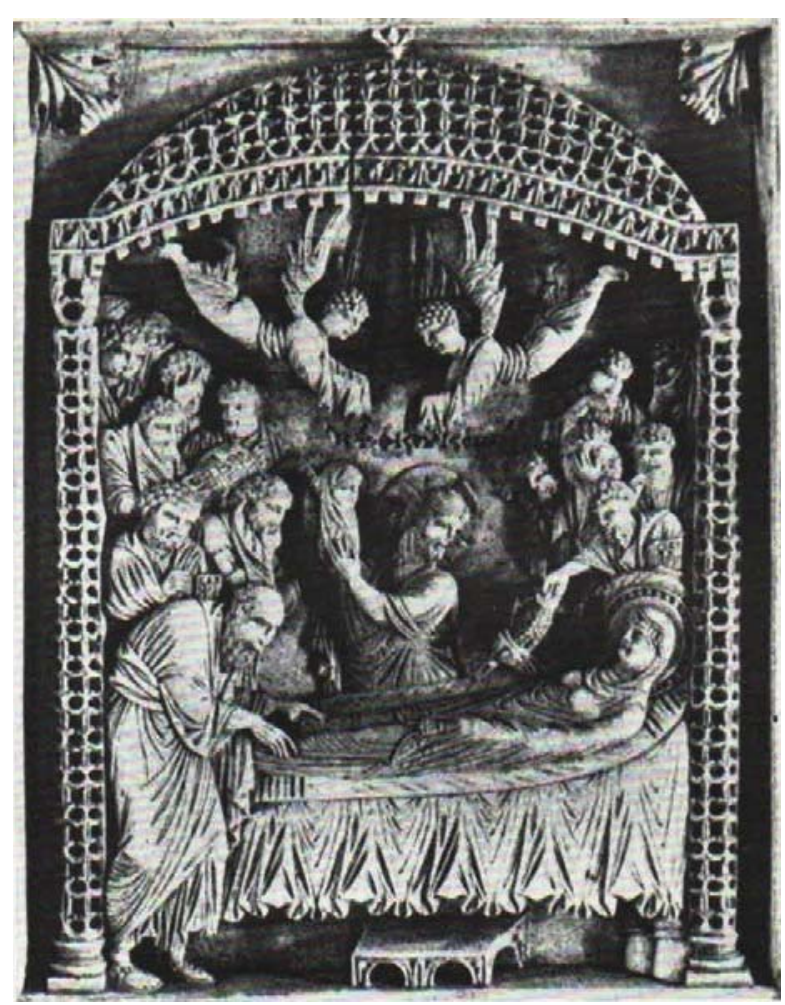

Fig. 4. Icono con Koimesis, marfil, ultimo cuarto del s. X. Bayerische Staatsbibliothek, Munich.

${ }^{49}$ Como ya se indicó, las dimensiones de los tres primeros iconos citados son 10,6 x 8,7 x 1,4 cm, 13 x 11,2 x $1,7 \mathrm{~cm}$ y $18,7 \times 14,9 \mathrm{~cm}$, respectivamente. 
En las dos piezas de Houston y Viena, el apóstol Juan -representado como un anciano de cabellera y barba canas, para significar su ancianidad en la isla de Pat$\operatorname{mos}^{50}$ — inclina con afecto su cabeza sobre el pecho de María. En los ejemplares de Viena, Munich, Cluny, Darmstadt, Houston y Nueva York, para significar el funeral en proceso, Pedro balancea un incensario, gesto apreciable - por la postura alzada de su brazo - incluso en los marfiles de Houston y Nueva York, pese a la desaparición en ambos de la mano y del incensario. Por vía de excepción, los iconos gemelos de Darmstadt y Cluny plasman dos veces el alma de la Virgen, una aún en brazos de Jesús, la otra ya en manos de un ángel, que, en el ángulo superior derecho, la conduce hacia el cielo.

Mucho más compleja que las anteriores es la estructura compositiva de la Dormición de un icono de la $2^{\mathrm{a}}$ mitad del siglo XI, del monasterio de Sta. Catalina en el Monte Sinaí, ${ }^{51}$ pieza que es apenas un fragmento (algo más de la mitad) de una composición mayor. En torno a Cristo portando el alma de María, representada como recién nacido fajado, se ven allí sólo seis apóstoles -entre ellos Juan acercando su cabeza al pecho de la Virgen, Pablo abrazando sus pies y Pedro con su brazo derecho (bastante deteriorado) en alto, casi con seguridad agitando un incensario ${ }^{52}$-, así como un santo obispo con omophorion ${ }^{53}$ de cruces negras (otro u otros dos obispos deberían haber sido plasmados en la parte faltante del panel), y tres mujeres en el interior de una casa, asomadas por las ventanas. En el cielo se observa una media docena de ángeles, tres de ellos llevando al paraíso el alma de María en la parte derecha, como también, en la parte izquierda, una aparente nube/alvéolo con dos personajes (¿ángel y apóstol? ¿dos apóstoles?), mientras, en el borde superior, un coro de serafines, con sus seis alas entrecruzadas en torno a sus cabecitas, forman un arco para simbolizar el edén celestial donde ingresará la Theotókos. De la identidad y el papel de esos santos obispos y de esas tres mujeres, así como de la naturaleza y la función de esas "nubes", hablaremos más adelante.

Las grandes restricciones narrativas impuestas al tema de la Koimesis por las breves dimensiones de los iconos en marfil, esteatita o tabla (como también en las miniaturas en pergamino, que analizaremos luego), desaparecen en las grandes superficies de los frescos murales que ilustran el tema. La amplitud en altura y anchura de esos murales permite al diseñador del programa iconográfico y al pintor desplegar una mayor cantidad de detalles descriptivos y contenidos doctrinales, los cuales tenderán a hacerse tanto más profusos y explícitos cuanto mayor sea la superficie parietal disponible.

Importantes, por su carácter prototípico, debido a su temprana fecha (con sus primeras manifestaciones en el siglo $\mathrm{X}$, como sostiene la mayoría de los expertos, e in-

\footnotetext{
${ }^{50}$ El evangelista Juan fue el único apóstol en fallecer de muerte natural, mientras todos sus restantes colegas sufrieron martirio.

${ }^{51}$ Repr. en LAZAREv 1967: s.p., fig. 323.

${ }^{52}$ De hecho, ése es el gesto y el instrumento que Pedro exhibe en otros iconos bizantinos, como los de Munich, Viena, Cluny, Darmstadt y Nueva York.

${ }_{53}$ Confeccionado con lana blanca decorada con cruces negras, el omophorion es, en la Iglesia ortodoxa oriental, una vestimenta ceremonial distintiva de los obispos, para significar su autoridad espiritual sobre los fieles.
} 
cluso, según otros, ya desde el s. IX) son las Dormiciones de las iglesias rupestres de Capadocia,${ }^{54}$ en especial, las del valle de Göreme. ${ }^{55}$ De entre las numerosas Koimesis murales capadocias, podemos resaltar las más representativas.

El programa iconográfico de la Tokali kilise ("iglesia en círculo" o "iglesia con ornamento", de San Basilio en Göreme 7), ${ }^{56}$ templo compuesto por tres partes -la iglesia antigua (Tokali 1), la Nueva Iglesia (Tokali 2) y una cripta funeraria ${ }^{57}$-, incluye una Koimesis, cuya datación oscila, según los expertos, entre inicios del siglo $\mathrm{X}^{58} \mathrm{y}$ mediados ${ }^{59} \mathrm{o}$ finales de esa misma centuria. ${ }^{60} \mathrm{Al}$ analizar esta Dormición muy deteriorada -que ocupa, frente a la Transfiguración, dos pequeños nichos intermedios en el corredor entre la prótesis y el ábside central ${ }^{61}$ de la Tokali $2^{62}$ - , resulta elocuen-

${ }^{54}$ Para estas Iglesias rupestres bizantinas de Capadocia y los programas iconográficos de sus respectivas pinturas murales resultan indispensables las monografías de Nicole y Michel THIERRY, Nouvelles églises rupestres de Cappadoce, Région du Hasan Dagin (Avant-propos par André Grabar), Paris: Klincksieck, 1963, 248 p. + il., s.p.; Spiro Kostof, Caves of God. The Monastic Environment of Byzantine Cappadocia, Cambridge, Mass / London: The MIT Press, 1972, 296 p.; Nicole ThIERRY, Haut Moyen-Âge en Cappadoce, Les églises de la région de Çavusin, Tome I, Paris: Librairie Orientaliste Paul Geuthner, 1983, 197 p. + il., s.p.; y Catherine Jolivet-LÉvy, Les églises byzantines de Cappadoce. Le programme iconographique de l'abside et de ses abords, Paris, Editions du CNRS, 1991, 392 p.+185 pl. Kostof se interesa por el aspecto morfológico de las arquitecturas, más que por los programas iconográficos, que considera, con bastante superficialidad, desde el punto de vista estilístico-formal.

${ }^{55}$ A propósito de estas iglesias rupestres capadocias Spiro Kostof apunta: "We might cite here the Dormition of the Virgin, present at Agaç Alt and Yilanli. The pictorial formulation of this theme, in whatever form, probably has its origin in post-Iconoclastic art. The earliest known example in monumental painting, East or West, is the detailed Dormition sequence in S. Maria de Gradellis in Rome at the end of the ninth century, program we have already encountered in the discussion of Basilian picture cycles." (Kostof 1972: 203).

${ }^{56}$ Jolivet-Lévy 1991: 94. Sobre el estilo de las pinturas murales de la Tokali kilisse dice Charles Delvoye. "Dans cet art populaire, sans grand savoir technique, se manifeste un sens réel de l'harmonie des couleurs. La composition est très dense: les personnages se serrent les uns contre les autres et occupent toute la hauteur de chaque zone. Les accessoires, les indications de paysages, sont autant que possible supprimés. La narration est vive, alerte, bien rythmée, riche en notations réalistes." (Delvoye 1967: 236).

57 JoLIVET-LÉvy 1991: 94.

58 Delvoye (1967: 236) data los frescos de la Tokali kilise a inicios del siglo X. Marie-Louise THÉREL (1984: 47) también los fecha en el siglo X.

${ }^{59}$ Según Carolyn L. Connor (1991: 40) la Dormición de la Tokali kilise, fechada, a su juicio, en la segunda mitad del siglo X, constituye uno de los ejemplos monumentales más tempranos de dicho tema mariano.

${ }^{60}$ Según Jolivet-Lévy, "La datation des peintures [de la Tokali kilise] vers le milieu du Xe siècle (930-960 environ), jadis proposée par G. de Jerphanion, demeure la plus vraisemblable et elle est confortée par les comparaisons possibles avec des ivoires et miniatures contemporains, ainsi qu'avec le décor du Pignonnier de Çavusin (963-969), qui fournit un terminus ante quem. Certaines particularités du programme iconographique suggèrent, d'autre parte, de localiser l'atelier de peintres actif à Tokali, dans la capitale régionale, Césarée de Cappadoce. M. Restle, cependant, après avoir placé le décor de Tokali 2 à la fin du $\mathrm{X}^{\mathrm{e}}$ siècle (avec des repeints postérieurs), attribue maintenant l'ensemble au XIII ${ }^{\mathrm{e}}$ siècle." (JolIVET-LÉvy 1991: 108).

${ }^{61}$ JoLIVET-LÉVy 1991: 102.

${ }^{62}$ Según Jolivet-Levy, "Les circonstances qui présidèrent à la fondation et au décor de la Nouvelle église [de la Tokali kilise] restent difficiles à préciser. Il s'agit à l'évidence d'un monument prestigieux, dû au patronage de personnages influents, qu'il est tentant d'identifier, avec Nicole Thierry, à des 
te la descripción que de ella hace Catherine Jolivet-Lévy. Según dicha especialista, la Koimesis de la Tokali 2 (Iglesia Nueva):

sigue un esquema avanzado e innovador, con Cristo entronizado en lo alto sobre el arco iris, rodeado de ángeles, y, a la derecha, los apóstoles que llegan sobre las nubes (representadas mediante una especie de medallones), como lo precisa la inscripción (en griego) oi apostolu erjómenu (epi ton) nefelon. En el nivel inferior, Cristo I(esou) $s X($ risto) $s$, de pie detrás del lecho, presentaba el alma de su madre a un ángel. María estaba recostada con la cabeza hacia la izquierda, Pablo inclinado a sus pies y Pedro probablemente en la cabecera. A los apóstoles se añaden en el dintel de una puerta tres mujeres llorosas; en el plano de atrás, se perfila un fondo arquitectónico. ${ }^{63}$

Junto a la excepcional Koimesis de la Kiliçlar kilise (Göreme 29, Capadocia), ${ }^{64}$ cuyas pinturas murales los expertos datan, por su estilo, a inicios o a mediados del siglo X ${ }^{65}$ sobresale además la Dormición de la Ayvali kilise ${ }^{66}$ (iglesia de San Juan, en Güllü Dere no 4, Capadocia) ${ }^{67}$ (Fig.5).

membres de la riche famille locale des Phocas. L'ampleur des proportions, le soin apporté au décor architectural, la richesse de la technique picturale, qui recourt au lapis-lazuli pour le bleu des fonds, à l'or pour certains nimbes, la complexité et la nouveauté de l'iconographie, la qualité du style enfin, sont exceptionnels." (Jolivet-LÉvy 1991: 108). Por el contrario, Charles Delvoye, al referirse a estas iglesias rupestres de Capadocia, en general, y a la Tokali kilise en particular (las cuales estima fechables como del siglo X, e incluso de fines del siglo IX, con influencias paleocristianas), ve en todas ellas una muestra de torpeza, decadencia y arcaísmo, al decir: "Le caractère populaire de cet art se manifeste dans le dessin, maladroit mais expressif et d'une grande spontanéité, et dans le goût pour la narration qui emprunte bien des éléments de l'illustration aux évangiles apocryphes, eux-mêmes nés de cette propension du peuple pour les belles histoires racontées avec force de détails. Le contraste est net avec l'art aristocratique et théologique de la capitale, qui se soumettait à une stricte discipline dans le choix et la répartition des sujets." (Delvoye 1967: 235-236).

${ }^{63}$ JoLIVET-LÉvy 1991: 102-103.

${ }^{64}$ Según Jolivet-LÉvy, (1991: 137) el programa iconográfico de la Kiliçlar kilisesi (Göreme 29), iglesia de estilo "arcaico", dedicada sobre todo el relato de la vida de Cristo, incluye excepcionalmente, en el muro sur, la Dormición de María, ausente por lo general en otras iglesias del mismo grupo.

${ }^{65} \mathrm{Al}$ respecto afirma Jolivet-Lévy: "Bien que les peintures de Kiliçlar, de belle qualité, aient été attribuées par $\mathrm{G}$. de Jerphanion à la fin du $\mathrm{X}^{\mathrm{e}}$ siècle, elles sont généralement placées aujourd'hui vers 900 (R. Cormack, M. Restle, N. Thierry, A.W. Epstein), sur des critères essentiellement stylistiques. Plusieurs particularités du programme iconographique s'accordent mieux, à notre avis, avec une datation postérieure au tout debout du $\mathrm{X}^{\mathrm{e}}$ siécle, dans le second quart, voire, comme l'a récemment proposé Judith Clavé, vers le milieu du siècle." (JoLIVEt-LÉvy 1991: 141). Lyn RodLey (1994: 159) también las fecha a inicios del siglo $X$.

${ }^{66}$ Repr. en Nicole ThIERRY 1983: s.p., pl. 72 d (conjunto) y pl. 73 (detalle); en THÉREL 1984. s.p., pl. VI; en Rodley 1994: 158, no 118 (detalle poco visible). Marie-Louise Thérel (1984: 47) data esta Koimesis de la Ayvali kilise en 913-920, datación que comparte Lyn Rodley (1994: 157).

${ }^{67}$ Nicole Thierry 1983: 159. Según Jolivet-Lévy (1991: 151-154), la Ayvali kilise no está en Göreme, sino a nueve kilómetros al suroeste de Ürgüp; es una sola iglesia y no tiene Dormición en su programa iconográfico. 


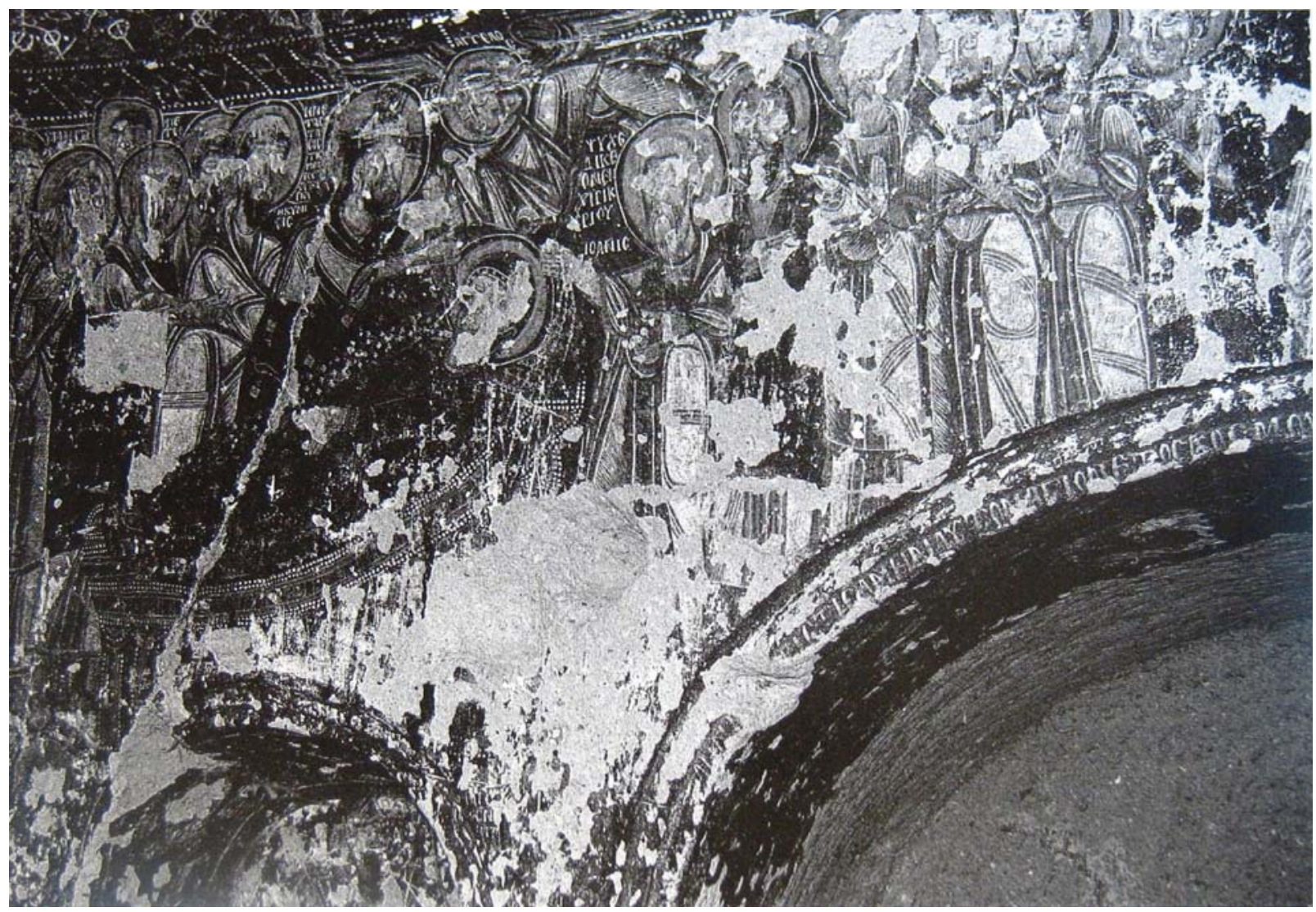

Fig. 5. Koimesis, fresco, s. X, Ayvali kilise, Güllü Dere no 4, Capadocia.

Ocupando la mitad occidental de la pared norte de la capilla norte, este fresco de la Ayvali kilise, hoy muy deteriorado y de datación muy discutida, ${ }^{68}$ es descrito con minucia por Nicole Thierry, quien destaca también las inscripciones epigráficas insertas en él. Conforme al análisis de dicha autora, el punto focal del cuadro es el particular diálogo gestual entre la moribunda Virgen, yacente en su lecho, y su hijo Jesús, inclinado ante ella para recoger su alma, la cual aparece representada como una figurita fusiforme envuelta entre bandas, que sale de su boca, en signo de haber exhalado su último suspiro. Volando sobre la cabeza de María, el arcángel Miguel acude a recibir el alma mariana entre sus manos, cubiertas por su propio manto. ${ }^{69}$ Tras indicar la ac-

68 Según Lyn Rodley (1994: 157), esta Koimesis data de 913-920, en el período macedonio, pues las dos iglesias gemelas autónomas, aunque comunicadas por un pasillo, que conforman el conjunto de la Ayvali kilise, están datadas por una inscripción en el reinado de Constantino VII. Sin embargo, JoLIVETLÉVY (1991: 154) confiesa que su fecha de ejecución resulta muy controvertida entre los especialistas, varios de los cuales la sitúan entre el tercer cuarto del siglo XI e incluso inicios del XIV, fecha ésta que ella considera demasiado tardía.

${ }^{69}$ Muy ilustrativo resulta el análisis que de esta Koimesis brinda Nicole Thierry: "Le sujet est défini par les inscriptions; à gauche de la tête de Christ: H METACTACIC TIC METPOC TOY KIPIOY, H KYMICIC (...) Le trépas de la Mère du Seigneur: La Dormition. La Vierge, vêtue du omophorion, est étendue au centre, ses deux bras sont posés sur elle, les mains croisées. Le lit est plat, porté par des gros pieds cylindriques. Le Christ (IC XC), situé en arrière, se penche vers sa mère pour saisir l'âme qui s'échappe de sa bouche comme un dernier souffle, ce geste du Christ, cette âme qui sort du corps, sont des images exceptionnelles pour l'iconographie traditionnelle de la Dormition. L'âme est une 
titud e identidad de algunos apóstoles,${ }^{70}$ Nicole Thierry no olvida destacar que "esta Dormición se aleja de la iconografía habitual por su carácter realista." ${ }^{י 11}$

La Koimesis de la Sakli Kilise ("iglesia escondida", Göreme 2 a, Capadocia) ${ }^{72}$ — datada en el siglo XI por la mayoría de los entendidos, ${ }^{73}$ y que ocupa con la Transfiguración el muro oeste del templo ${ }^{74}$ — presenta sobre un fondo abstracto una composición muy simple y plana, con escasos personajes y sin decorado arquitectónico. Relativa similitud con la de la Sakli kilise ofrece la Koimesis de la Yilanli kilise ("iglesia de las serpientes"), en Capadocia ${ }^{75}$ si bien ésta última presenta como novedad excepcional la ausencia absoluta del cuerpo de la Virgen María, ausencia que Nicole y Michel Thierry interpretan como el instante mismo de la muerte de la Madre de Dios. ${ }^{76}$

curieuse petite figure à corps fusiforme enveloppé de bandelettes, seul son aspect effilé la différencie des représentations habituelles semblables à celles d'un enfant dans ses langes. L'inscription accompagne le geste du Christ: PSYCHENDIKEON EN XIPI KYRIOU (...). Les âmes des justes (sont) dans la main du Seigneur. L'ange psychopompe (AGGELOC) vole au-dessus de la tête de Marie, les deux mains tendues sous un pan de manteau pour recevoir l'âme." (Nicole THIERRY 1983: 159).

${ }^{70}$ De gran interés es el resto del comentario que Nicole Thierry hace de esta Dormición de la Ayvali Kilise: "Les apôtres, seuls assistants de cette scène, sont groupés de part et d'autre du lit; on voit écrit à chaque extrémité Y MAZITE les disciples. A la tête du lit, Jean (IONAIC) barbe et cheveux blancs, agite l'encensoir de la main droite et tient la botte à encens dans l'autre. Paul est derrière, reconnaissable à sa calvitie et à sa barbe noire. Les quatre derniers apôtres ne sont pas nommés non plus. Aux pieds de Marie se tient Pierre (ПЕТРОС), serrant contre lui une botte à encens (?) et avançant vers le Christ comme s'il lui parlait. Derrière lui on reconnaît André à ses cheveux hirsutes; en arrière on voit encore quatre apôtres anonymes. Ainsi, seuls Pierre et Jean son nommés." (Nicole ThiERry 1983: 159).

${ }^{71}$ La autora prosigue diciendo que esta Koimesis de la Ayvaly kilise "illustre le moment où le Christ saisit l'âme de sa mère pour la confier à l'ange psychopompe, cependant que Pierre l'interroge: «Qui d'entre nous a l'âme aussi blanche que Marie? » Et le Seigneur répond: « Ceux qui se gardent du pêché. » Le texte de l'apocryphe assimile la Vierge aux justes, comme l'inscription de la peinture tirée du Livre de la Sagesse 3, 1: «Les âmes des justes sont dans la main du Seigneur ». On comprend bien qu'il s'agit là d'une image préférentielle des décors funéraires, le salut de Marie pouvant servir de préfiguration au sort du chrétien. Marie elle-même étant la meilleure figure d'intercession auprès du Christ-juge." (Nicole THIERRY 1983: 159).

${ }^{72}$ Repr. en Coche de la Ferté 1981: 382, fig. 328 (detalle de la Virgen, Cristo y Juan).

73 Stierlin 1988: 112; Jolivet-Lévy 1991: 85-87. Según Jolivet-Lévy (Ibid.), el conjunto de la decoración pictórica de la Sakli kilise en Göreme 2 a (iglesia de San Juan Bautista) puede ser atribuida a mediados o al tercer cuarto del siglo XI, si bien esta investigadora ve dos autorías contemporáneas en distintos sectores del templo (Ibid.: 87).

74 Jolivet-LÉvy 1991: 86.

${ }^{75}$ Repr. en Nicole et Michel Thierry 1963: s.p., pl. 51 b (conjunto); pl. 52 a (detalle de Jesús y ángel); y pl. 52 b (detalle de apóstoles y lecho). Marie-Louise Thérel (1984: 47) afirma que esta Koimesis de la Yilanli kilise es anterior al siglo X.

${ }^{76}$ En referencia a esta Koimesis de la Yilanli kilise, Nicole y Michel Thierry afirman: "Il s'agit d'une iconographie de la Dormition unique jusqu'à présent. La couche funèbre vide ne permet pas le doute: ce n'est pas le cercueil fermé des funérailles, qui serait plus épais (la présence de Jéphonias n'est pas un argument, car il est souvent représenté dans les Dormitions traditionnelles); ce n'est pas non plus le tombeau d'après l'assomption. C'est le moment même de la mort de la Vierge qui est illustré; Jésus vient d'arriver, suivi de l'archange Michel, et a recueilli l'âme de Marie. L'inscription, dont il ne reste que les premières lettres, ne permet pas d'expliquer cette image, qui ne répond pas aux textes connus. En Cappadoce, les représentations de cette scène s'apparentent à l'iconographie byzantine traditionnelle. De même, la petite figure nue dans la main du Christ et le geste de l'ange du Seigneur sont des détails 
En la iglesia de la Theotókos en El-Adra (Egipto), en Deir es-Surian ("monasterio de los sirios"), edificado por los coptos en el siglo X en el desierto de Ouadi Natrun, a cien kilómetros de Alejandría, ${ }^{77}$ hay un fresco de la Dormición, ${ }^{78}$ datado por Henri Stierlin en $980,{ }^{79}$ como los restantes frescos de ese templo monástico ${ }^{80}$ Con una composición en extremo simple y sobre un fondo abstracto, apenas perfilado por un arco azulenco lleno de estrellas, denotativo del paraíso celeste, en este mural egipcio María luce dormida en su lecho funerario, flanqueada por varios apóstoles, mientras su alma (como neonato fajado) es sostenida en brazos por Cristo, bajo la atenta mirada de dos ángeles, que montan guardia de honor en sendos clípeos, agitando cada uno un flabellum. ${ }^{81}$

Un planteamiento de la Koimesis sustancialmente análogo se observa durante el siglo XI en los murales bizantinos de los Balcanes y de Grecia. Así, formando parte de un conjunto de frescos, de clara influencia constantinopolitana, plasmados en la catedral de Santa Sofía en Ohrid (República de Macedonia), ${ }^{82}$ la escena de la Dormición, ${ }^{83}$ situada en el muro oeste,${ }^{84} \mathrm{y}$ fechable entre 1037 y $1056,{ }^{85}$ no sólo marca un avance en su técnica y su estilo, ${ }^{86}$ sino que comienza a asumir una creciente

propres à la Dormition d'Yilanli kilise." (Nicole y Michel ThIERRY 1963: 106). Marie-Louise Thérel (1984: 47) afirma que la figura de la Virgen en esta Koimesis de la Yilanli kilise ha sido borrada por las aguas de lluvia.

77 STIERLin 1988: 112.

${ }^{78}$ Repr. en color en Stierlin 1988: 113, fig. 100.

${ }^{79}$ Marie-Louise ThÉRel (1984: 48) fecha esta Dormición en el primer cuarto del s. X, aceptando la opinión de H.G.E. White, quien los fecha en 926-927. (Ibid., nota 242).

${ }^{80}$ Stierlin afirma que, pese a la presencia islámica en Egipto, los coptos representaron estos frescos (hoy muy deteriorados) con un estilo firme y despojado, con un grafismo incisivo y colores netos, que revelan un artista de calidad. Sostiene además que esta fuente siria de los monjes podría explicar los estrechos parentescos entre estas pinturas y las coetáneas de Capadocia. (STIERLIN 1988: 112).

${ }^{81}$ Así analiza Marie-Louise Thérel este mural: "Dans un monastère syrien de la Haute-Égypte, à ElAdra, une fresque, daté du I ${ }^{\text {er }}$ quart du $\mathrm{X}^{\mathrm{e}}$ siècle représente, dans l'abside nord de l'église, la Dormition de la Vierge accompagnée, peut-être, de son Assomption. L'image de Marie, étendue sur son lit, est conforme à l'image de la Koimesis, mais d'autres détails viennent s'y ajouter. Aux côtés du Christ qui recueille l'âme de sa Mère, deux archanges portent un flabellum tandis qu'au sommet de la conque, deux anges supportent une mandorle. Malheureusement la détérioration de la voûte ne permet pas de distinguer la figure inscrite dans la gloire. Il est vraisemblable qu'elle représentait la Vierge Marie emportée au paradis." (THÉREL 1984: 48).

${ }^{82}$ Según Henri Stern (1966: 108-109), los frescos de la catedral de Santa Sofía de Ohrid, datados de 1037 a 1052, hechos por este episcopado autocéfalo, erigido tras la derrota del zar Simeón de Bulgaria a manos de Basilio II (1017), favorecía la influencia de Constantinopla, pues su arzobispo León era amigo del patriarca Miguel Cerulario y su aliado en la lucha contra el primado de Roma, por lo cual hizo venir artistas constantinopolitanos para realizar esas pinturas.

${ }^{83}$ Repr. en Tацвот Rice 1968 [1935]: 262, fig. 234.

${ }^{84}$ Según Tania Velmans (1999: 122), entre los frescos del naos de la iglesia de Santa Sofía de Ohrid, del ciclo de las grandes fiestas litúrgicas, sólo se conservan la Natividad y la Dormición de la Virgen.

${ }^{85}$ Henri Stern los data de 1037 a 1052; Velmans (1999: 104) los fecha en 1040; Talbot Rice (1968 [1935]: 262-265) los sitúa hacia 1050 ó poco antes de 1056.

${ }^{86}$ A juicio de Talbot Rice, esta Dormición de Santa Sofía de Ohrid, pese a sus colores sombríos, exhibe un dibujo excelente y su composición es balanceada, dignificada y bien hecha, con una cualidad bastante notable en su conjunto, por lo cual, al considerarla una gran obra, verdadero ejemplo del mejor 
relevancia iconográfica ${ }^{87}$ en función de las enseñanzas teológicas de ciertos Padres de la Iglesia oriental. ${ }^{88} \mathrm{~A}$ la ya clásica composición sencilla, centrada en torno a la horizontal Virgen, yacente en su cama entre dos grupos de apóstoles (más los tres santos obispos), y al vertical eje de Cristo portador del alma mariana entre dos ángeles que revolotean con velos rituales en sus manos, esta Koimesis de Santa Sofía de Ohrid añade como novedad dos grandes nubes o alvéolos en el cielo, simétricamente dispuestos en ambas esquinas superiores, cada uno de los cuales aloja a seis personajes (los apóstoles) en vuelo.

De entre las decoraciones murales de la iglesia de la Dormición en Dafni, cerca de Atenas, fechables c. 1080, destaca sobre la puerta principal en el muro oeste del naos el mosaico de la Tránsito de la Virgen. ${ }^{89}$ Aun cuando no debe ser exagerado, el indudable carácter pionero de esta Koimesis musiva griega ${ }^{90}$ supone un notorio avance doctrinal, en concordancia con el creciente culto a la Madre de Dios y con el fortalecimiento de una mariología cada vez más explícita y taxativa. ${ }^{11}$

La iglesia principal del monasterio de Hosios Lukas, en Fócida (Grecia), cuyos mosaicos y frescos datan de hacia 1040, ${ }^{92}$ tiene en los lunetos de su cripta algunas escenas de las grandes fiestas, incluyendo la Dormición..$^{93}$ Aun en mal estado de conservación (cada rostro ha sido raspado), ${ }^{94}$ este fresco muestra el tradicional tratamiento de este tema mariano: tras la Virgen, yacente sobre un lecho, que los apóstoles

estilo de la pintura monumental medio-bizantina, la supone pintada por un maestro con estrechos vínculos con Constantinopla. (ТАLвот Rice 1968 [1935]: 262-265).

${ }^{87}$ Según Velmans (1999: 122), para entonces (c. 1040) la Koimesis era un tema poco difundido aún, y desde entonces se hace casi obligatorio.

${ }^{88}$ A juicio de Velmans (1999: 122), la iconografía de Sta. Sofía de Ohrid expresa plásticamente el valor místico de las homilías de los santos Basilio y Juan Damasceno.

${ }^{89}$ Repr. en Nieto 1950: s.p., fig. 32. Conforme a Charles Delvoye, la Koimesis que decora la iglesia de la Dormición en Dafni fue colocada en el muro oeste del naos, sobre la puerta que viene del nártex "en el lugar que este tema ocupará cada vez con mayor frecuencia." (Delvoye 1967: 232). Cf. asimismo Velmans 1999: 124.

90 Según Charles Diehl, el ejemplo más antiguo de la Dormición de María "se encuentra en Daphni, donde, colocado encima de la puerta de entrada, termina la serie de las (grandes) fiestas", como consecuencia de la creciente devoción a la Virgen, cuya vida, extraída de los Evangelios apócrifos, se ilustra con creciente frecuencia a partir del siglo XI." (DieHL 1926, Tomo II: 500).

91 Tania Velmans comenta al respecto: "Este desarrollo del ciclo de las grandes festividades testimonia, a pesar de su valor dogmático, una tendencia narrativa nueva. El deseo de contar es una concesión de tipo humanista con relación al laconismo severo del pasado. En Dafni aparece además acentuado por la presencia del relato de la Infancia de María que decora el nártex. La Dormición de la Virgen en el muro oeste del naos, conservará generalmente este emplazamiento en el futuro. En la escena simplificada con Cristo portando el alma de su Madre, y los apóstoles reunidos alrededor del lecho mortuorio de María, se añaden ahora tres santos obispos: Dionisio el Areopagita, Santiago hermano del Señor y obispo de Jerusalén, Hieroteo y a veces Timoteo. El ciclo de la Vida de María no se corresponde con ningún texto canónico sino con episodios del protoevangelio de Santiago y otros relatos apócrifos." (Velmans 1999: 124-125).

92 Según Velmans (1999: 104), los mosaicos y los frescos de la iglesia principal del monasterio de Hosios Lucas en Fócida, datan de c. 1040, y presentan un estilo similar a los de la iglesia de Santa Sofía en Ohrid, que son de la misma fecha.

${ }_{93}$ Connor 1991: 11 y 40; Velmans 1999: 104.

${ }^{94}$ Repr. en ConNor 1991: s.p., fig. 77. 
flanquean por la cabecera y los pies, aparece Cristo en el centro, sosteniendo entre sus brazos el alma infante de su madre, mientras dos pequeños ángeles sobrevuelan en simétrica pose la escena, entre un sencillo implante arquitectónico de dos pequeñas construcciones a ambos extremos del luneto.

\subsubsection{La Koimesis bizantina en el siglo XII}

Tanto en los pequeños iconos como en los grandes murales, el tema iconográfico de la Dormición de María experimenta durante el siglo XII en el arte bizantino una apreciable complicación compositiva y una creciente profusión de detalles narrativos, al asumir cada vez con mayor desenfado los inauditos relatos apócrifos. Cierto es que, por la constricción espacial impuesta por sus reducidas dimensiones, algunos iconos suntuarios bizantinos del siglo XII conservan aún la extrema sencillez compositiva, la escasez de personajes y la ausencia de escenografía que vimos en los primeros iconos de los siglos X y XI, descritos al inicio de nuestro artículo. Semejante propuesta sintética en algunas piezas suntuarias bizantinas del siglo XII se observa, por ejemplo, en la Koimesis en marfil del Museo del Ermitage en San Petersburgo, y en la del icono en esteatita con las doce Grandes Fiestas, perteneciente al Tesoro de la catedral de Toledo. ${ }^{95}$

No obstante, los iconos bizantinos de la Dormición tienden a adquirir en el siglo XII una complejidad cada vez mayor. Relativa sencillez conserva todavía la Koimesis de la predela de un icono búlgaro de la Virgen de la Ternura, ${ }^{96}$ icono datado hacia los siglos XI-XII, proveniente del monasterio de Zarzma, hoy en el Museo de Arte Georgiano en Tblisi: ${ }^{97}$ aunque incompleta, por faltarle una ancha franja a la izquierda, esta Dormición búlgara ofrece los lineamientos esenciales, con la Virgen sobre un rico lecho con peana, siete apóstoles compungidos (Pedro con incensario y Juan inclinándose sobre el pecho de María), Cristo sin mandorla sosteniendo el alma de su madre, un ángel en vuelo con sus manos veladas, y dos escuetas casas a la derecha.

Mayor riqueza narrativa y doctrinal se aprecia en el ejemplar de un icono procedente del monasterio de Novgorod, hoy en la Galería Tretiakov de Moscú.$^{98}$ Pese a la sencillez de su estructura y a la absoluta ausencia de decorado arquitectónico, esta pieza rusa introduce -junto a la convencional disposición de Cristo, María, los doce apóstoles y cuatro ángeles revoloteando en el centro de la escena- varias novedades de interés: sobre la convencional presencia de los tres santos obispos, revestidos con omophorion crucífero, se observan doce "nubes", cada una de ellas conteniendo un

${ }_{95}$ Repr. en Nieto 1950: s.p., fig. 38; en TALBOT Rice 1968 (1935), fig. 423, p. 456, y en Coche De LA FERTÉ 1981: 427, fig, 548, y p. 457, nº 548.

${ }^{96}$ Rodean a dicho icono por sus cuatro costados, a modo de marco o predela, las escenas de las doce grandes fiestas litúrgicas de la Iglesia oriental, entre ellas, la Dormición de María.

${ }^{97}$ Repr. en Velmans 2001, 498, fig. 237 (conjunto del icono), y p. 499, fig. 241 (Dormición).

${ }^{98}$ Repr. en Alpatov 1976: s.p., fig. 21 (detalle) y fig. 22 (conjunto). En esta Koimesis, de composición sencilla y sin arquitecturas, se observa a Cristo, María, los apóstoles y los santos obispos, así como doce nubes, cada una con un ángel y un apóstol, más cuatro ángeles en el centro, y arriba un semicírculo con ángeles en la "entrada", representando el cielo. 
apóstol, mientras en el borde superior del panel dos ángeles conducen el alma de María hacia un semicírculo azul, para ilustrar su asunción espiritual al cielo.

Relativa complejidad exhibe asimismo la Dormición de la Virgen, fechable a fines del siglo XII o inicios del XIII, ${ }^{99}$ integrante del iconostasio del monasterio de Santa Catalina en el Monte Sinaí. ${ }^{100}$ De diagramación sencilla, como la de los precedentes ejemplares, este icono sinaítico presenta los mismos personajes y situaciones, incluyendo a Cristo sin mandorla, sosteniendo el alma de su madre, con las únicas variantes de incluir un santo obispo, distinguible en el sector izquierdo por su vestimenta episcopal, y de poner como decorado urbano dos sintéticos edificios, cupuliforme el de la izquierda, y con frontón triangular el de la derecha. ${ }^{101}$

La exuberancia iconográfica de la Koimesis se acrecienta de modo notable en los mosaicos y frescos bizantinos del siglo XII. Así se observa en la iglesia monástica de la Panagia Phorbiotissa en Asinou, Nicosia (Chipre), cuyas pinturas murales ejecutaron en 1105-1106 anónimos artistas constantinopolitanos, ${ }^{102}$ por encargo y patrocinio del magistros Nicéforos, bajo el reinado del emperador Alexis Comnenos. ${ }^{103}$

Entre esos frescos de la Panagia Phorbiotissa en Asinou (Fig.6), muy elogiados por algunos especialistas, ${ }^{104}$ la Dormición, pintada en el muro oeste de la nave, ${ }^{105}$ refleja

${ }^{99}$ Weitzmann 1980c: $222, \mathrm{n}^{\circ} 57$.

100 Repr. en Weitzmann, Chatzidakis, Miatev y Radojcic 1968: s.p., pl. 35 (en color); en Weitzmann, Chatzidakis, Radojzic 1980b: 57, fig. 57; y en Wharton 1988: 78, fig. 3.17.

${ }^{101}$ De esta Koimesis dice Kurt Weitzmann: "Outguardly the general impression is of greater calm. The turbulent treatment of the draperies is abandoned in favor of a much more simplified approach. However, the emotional element is not only retained, but has, in fact, been intensified through the coloristic means of a freer brush technique. (...) Instead of the traditional emphasis on strong local colors, the painter of the Dormition preferred subdued colors such as olive green in sensitive nuances and tones; these, by means of the symbolic values associated with colors, help bring out the funereal significance of the scene." (WEITZMANN 1980b: 24).

102 Velmans 1999: 137-138.

${ }^{103}$ A juicio de Charles Delvoye, "Les fresques exécutées dans l'église de la Panagia Phorbiotissa à Asinou en 1105-1106, grâce a la générosité du magistre Nicéphore, présentent le grand intérêt d'être les seules oeuvres de la peinture byzantine du début du XII siècle sûrement datée." (Delvoye 1967: 243). Según Lafontaine-Dosogne (1987: 161-162), la decoración pictórica de la Panagia Phorviotissa de Asinou fue concebida en 1105-1106 por el magister Nicéforo, alto funcionario y probablemente general de Alexis I (tales frescos fueron repintados en parte e incluso modificados en el siglo XIV, aunque muchos conservan su estado original, entre ellas algunas Grandes Fiestas). La misma autora afirma: "la beauté des visages, la variété très étudiée des attitudes, la façon de souligner par le drapé les hanches et les cuisses rappellent Daphni, avec moins de grâce mais plus de vigueur. La douleur s'exprime plus fortement dans la Dormition de la Vierge —dans cette fresque apparait pour la première fois dans la peinture d'église, semble-t-il, le motif des femmes en déploration dans les baies d'un édifice." (LAFontaine-Dosogne 1987: 162).

${ }^{104}$ No pocos expertos han destacado la grave belleza de estos frescos de Asinou. Charles Delvoye, por ejemplo, dice que "elles montrent un goût pour la sveltesse des silhouettes, la vivacité des mouvements et une harmonieuse élégance des formes qui les apparente aux mosaïques de Saint-Démétrius (ou Saint-Michel) de Kiev." (Delvoye 1967: 243). Annabel Jane Wharton, por su parte, sostiene que los frescos de la Panagia Phorbiotissa en Asinou fueron hechos con grave simplicidad, y sus personajes principales tienen cierta presencia monumental frente a la pintura plana, mientras las figuras secundarias son más pequeñas y menos numerosas, si bien todas tienen una expresividad emotiva contenida, como lo manifiesta el hecho de que "the gestures of the apostles in the Koimesis are evocative of intense emotion, but except for tragic, linearbrear lines, the figures are only decorously dramatic in their expressions of grief." (WHARTON 1988: 78-79).

${ }^{105}$ Repr. en Guillou 1974: s.p., pl. VIII (color); en WharTon 1988: 78, fig, 3.17; en color en Evans, Wixom (eds.) 1997: 112; en Velmans 1999: 138, fig. 121. 


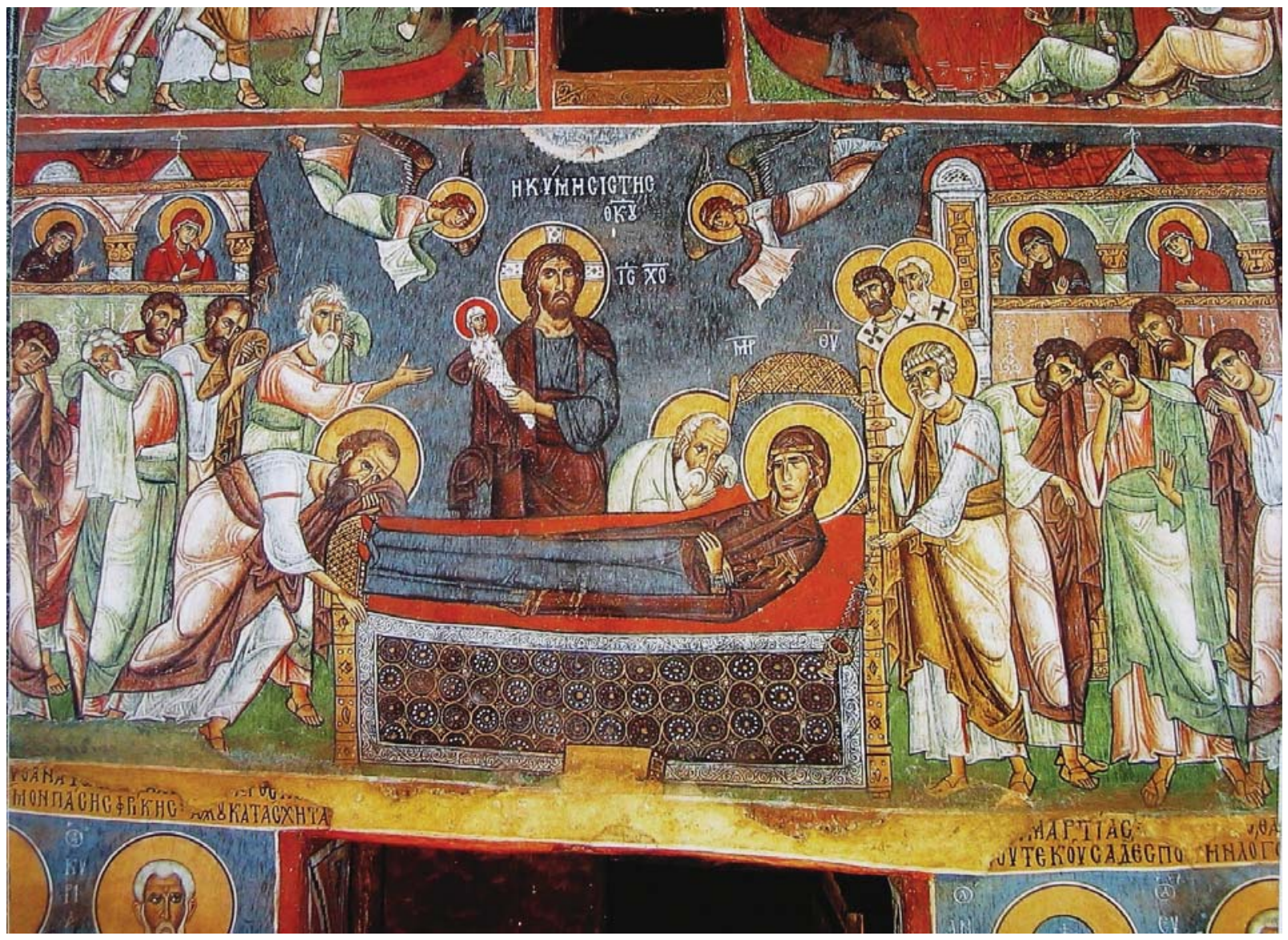

Fig. 6. Koimesis, fresco, 1105-1106, Panagia Phorbiotissa, Asinou (Chipre).

la estructura compositiva tradicional: los dos grupos de apóstoles rodeando el lujoso lecho de María (cuya cabeza se orienta hacia la derecha) y dos santos obispos revestidos con indumentaria episcopal de cruces negras escoltan a Cristo ( sencillo nimbo crucífero) portando el alma de la Virgen bajo el breve arco refulgente (el cielo abierto), mientras dos ángeles en vuelo se aprestan a recibir en sus manos veladas el alma mariana. Relativa novedad en este mural de Asinou es la presencia de dos mujeres llorosas (son las mismas dos damas, aun cuando duplicadas en dos circunstancias diferentes), observables a través de las ventanas de sendos edificios, situados en pendant a ambos lados de la composición.

Entre los frescos de la iglesia monástica de la Panagia Mavriotissa en Kastoria (Macedonia, Grecia), de datación muy discutida, ${ }^{106}$ y de estilo vigoroso y expresivo, ${ }^{107}$ la

106 Fechado por algunos en el siglo XI (WharTon 1988: 115), y por otros en el siglo XII, Tania Velmans, por el contrario, siguiendo a otros expertos (que menciona), lo data antes de 1295, añadiendo además que estos frescos del despotado de Epiro, en el Norte de Grecia, de estilo bastante provincial, presentan un programa que por lo general tiene en cuenta las innovaciones iconográficas de la época. (Velmans 1999: 201-202).

107 Según Annabel Jane Wharton (1988: 115), la Koimesis de la Panagia Mavriotissa en Kastoria -que sitúa en el siglo XI, considerándola de autoría regional- posee intensa expresividad, fundada en el fuerte contraste de colores, incluyendo el uso extensivo del negro, y la dramática exageración de los personajes y los gestos. Tales rasgos, según la autora, revelan la intención de exagerar el estilo 


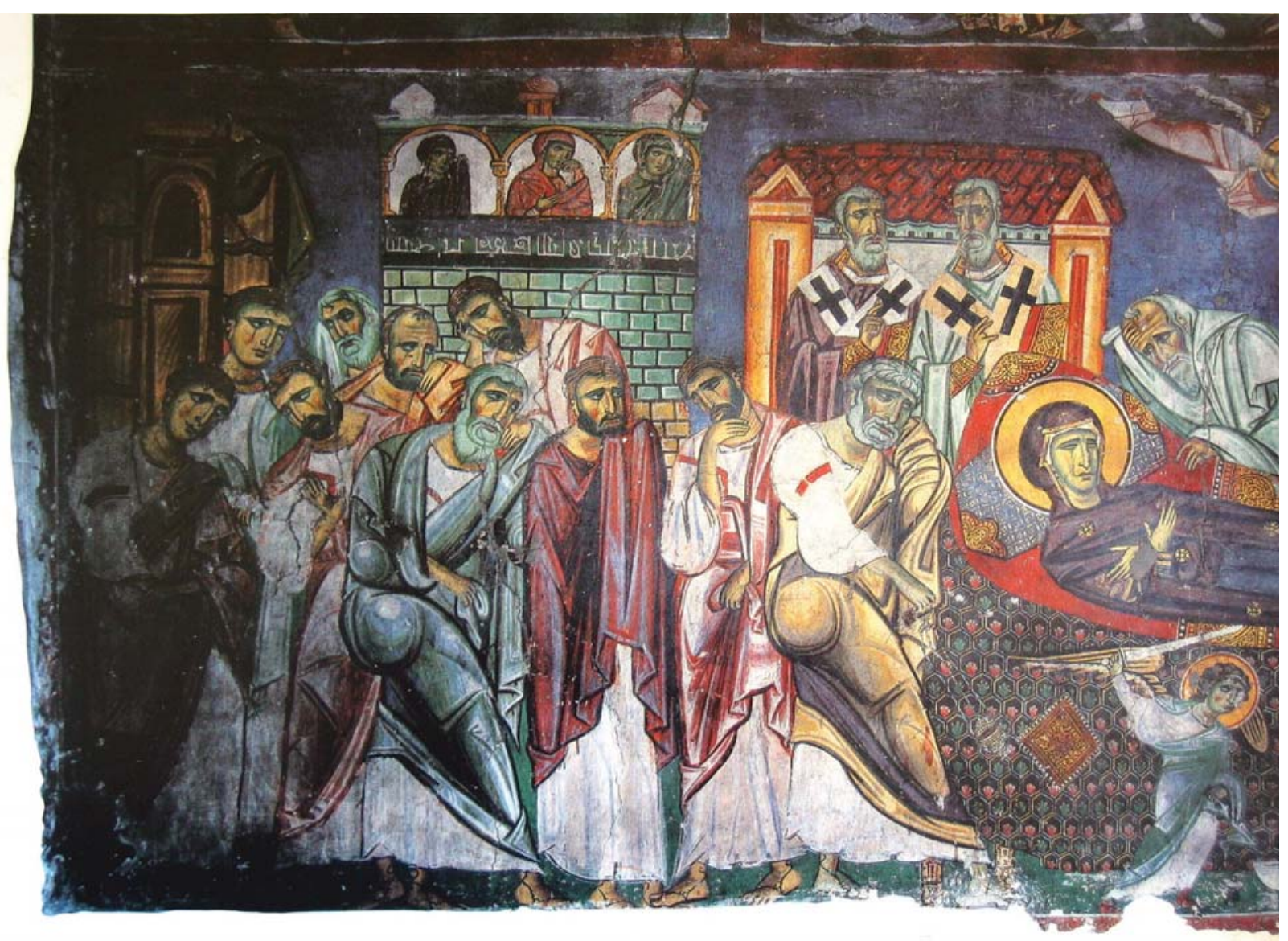

Fig. 7. Koimesis (mitad izquierda), fresco, c. s. XII, Panagia Mavriotissa, Kastoria (Grecia).

Koimesis, ${ }^{108}$ situada sobre el muro oeste, ofrece un interesante conjunto de novedades sobre el esquema convencional (Fig.7). A la cabecera del suntuosamente recamado lecho de María, ataviada con lujosos vestidos, se agolpan todos los apóstoles (presididos por Pedro, apoyado sobre la cama), a excepción de Juan y Pablo, quienes, inclinándose sobre el pecho de la Virgen y abrazando sus pies, respectivamente, cumplen en su lugar de costumbre su tradicional cometido. Sin mandorla de gloria y con sencillo nimbo en cruz, Cristo eleva hacia su izquierda (derecha del cuadro) el alma de su madre, que vienen a recoger dos pequeños ángeles, de manos cubiertas por velos rituales. Por detrás de Pablo, contrabalanceándose en el sector derecho con los diez apóstoles agrupados, una pléyade de grandes arcángeles, lujosamente engalanados con vestidos imperiales y portando báculos, sirven de guardia de honor a la moribunda Theotókos. Sobresale además en el fondo de este fresco de la Panagia Mavriotissa de Kastoria la escenografía arquitectónica, compuesta por cuatro edificios, uno de los cuales sirve para enmarcar exteriormente las figuras de dos santos obispos, revesti-

dramático de los murales de Santa Sofía de Ohrid, lo cual ha llevado a algunos a pensar que el pintor era un artista local, que había trabajado con el maestro de las pinturas de la catedral arzobispal de Santa Sofía de Ohrid.

${ }^{108}$ Repr. en Wharton 1988: 114, fig. 4.16 (detalle) y fig. 4.17 (diagrama de conjunto); y en Velmans 1999: 225, pl. 86 (sólo la mitad izquierda del fresco). 
dos con omophorion crucífero, mientras otras dos casas albergan en su interior a tres mujeres en el sector izquierdo y a otras dos damas en el lado derecho. Por si fuera poco, se incluye también en el centro del borde inferior la escena del ángel cortando con su espada los brazos del judío profanador, lo cual supone en este fresco la sincronía de dos momentos diferentes, al mezclar en una única composición los sucesivos episodios del tránsito de la Virgen y el traslado de su féretro en cortejo fúnebre para su sepelio.

Entre los frescos de la iglesia de San Nicolás Kasnitzes, en Kastoria (Macedonia, Grecia), cuyo programa iconográfico manifiesta en conjunto una cierta irregularidad, ${ }^{109}$ y cuyo estilo un tanto manierista algunos expertos relacionan con el de Nerezi ${ }^{110}$ la Koimesis, pintada al fresco a fines del siglo XII (c. 1191) ${ }^{111}$ ofrece un esquema compositivo convencional: todos los personajes (dos grupos de apóstoles, más dos obispos) y los elementos escenográficos (dos edificios) se disponen en balance simétrico en torno a la coordenada de Jesús portando el alma de María, y la abscisa de la Virgen yacente, con la cabeza orientada hacia la derecha del cuadro. Único elemento sin referente análogo simétrico es la pareja de ángeles situados en vuelo a la izquierda de Cristo para recibir el alma mariana entre sus manos veladas, ángeles que, de todos modos, mantienen cierta correspondencia compositiva ("simetría" virtual) con las inscripciones epigráficas (IC XC / H KOIMHCIC $)^{112}$ insertas a la derecha del Redentor.

Formando parte de los admirables mosaicos que decoran la iglesia de la Martorana (Santa María del Almirante) en Palermo, hechos casi con seguridad por artistas griegos, ${ }^{113}$ la Dormición musiva, ${ }^{114}$ ejecutada entre 1143 y 1151 (como los restantes mosaicos de ese templo) ${ }^{115}$ en una de las bóvedas secundarias, ha sido objeto de incontables elogios, no sólo por su antigüedad ${ }^{116}$ y su relativo carácter pionero, ${ }^{117}$ sino

109 Según Wharton, las desarticuladas superficies de la iglesia de San Nicolas Kasnitzes en Kastoria conllevaron a una narración continua, no concebida arquitectónicamente. Por ejemplo, al no estar centrada la Koimesis en el muro oeste sobre la entrada de la nave, sino estando desplazada a la izquierda para dejar espacio a una Transfiguración más pequeña, condujo quizá al artista a invertir la posición normal de la Virgen, para reforzar el movimiento de los ojos de izquierda a derecha. Al este las vírgenes orantes aparecen en el ábside, mientras en el frontón aparece la Deisis. (WHARTON 1988: 122).

110 Según Wharton (1988: 123), las pinturas de esta iglesia de San Nicolás Kasnitzes en Kastoria se relacionan con las de Nerezi, por sus figuras alargadas, con rasgos dramáticamente delineados, independizándose del plano sobre el que actúan.

${ }^{111}$ Repr. en COCHe de la Ferté 1981: 390, fig. 372; en Wharton 1988: 122, fig. 4.21.

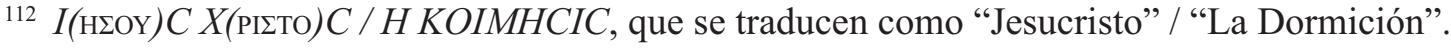

113 A juicio de Henri Stern (1966: 112), los mosaicos de la Martorana de Palermo (entre ellos la Koimesis en una de las bóvedas secundarias) han sido atribuidos a artistas griegos, como la mayor parte de los mosaicos del grupo sículo-normando.

114 Repr. en Diehl 1926, Tomo II: 551, fig. 261; en LaZARev 1967, s.p., fig. 358; en Delvoye 1967; 346, fig. 130; en Talbot Rice, 1968 [1935]: 213. fig. 189; en Schug-Wille 1969: 193 (color).

${ }^{115}$ Esta fecha final de 1151 es compartida por Delvoye (1967: 346); Schug-Wille (1969: 193) y TALbot Rice (1968; 313).

116 Según Charles Delvoye (1967: 237), la Koimesis de la Martorana, "est une des plus anciennes, après celle de Daphni, dans la peinture murale et aussi une des plus dépouillées". A su vez, SchUGWille (1969: 193) sostiene que esta Dormición de Palermo es después de la de Dafni, la más antigua interpretación de este tema a gran escala.

117 Según Schug-Wille (1969: 193), esta Koimesis de la Martorana, por su armonía entre figuras y arquitectura, se acerca mucho a las esquemáticas convenciones de los iluminadores de manuscritos 
además por su convincente expresividad ${ }^{118}$ y su profusión narrativa ${ }^{119}$ (Fig.8). También aquí la diagramación se organiza en perfecta simetría: siete apóstoles a los pies del lecho, encabezados por Pablo, a los que responden, en la cabecera, otros cuatro apóstoles y tres santos obispos, presididos por Pedro, que agita un incensario, manteniéndose ambos grupos en perfecta sintonía con los dos grandes ángeles que vuelan en el centro y con los dos edificios erigidos a derecha e izquierda del cuadro, con la única disparidad de que sólo la casa de la derecha se halla habitada por dos mujeres en llanto. En el centro, se observa una vez más la previsible trama de la horizontal María yacente en el lecho, el vertical Jesús levantando en sus brazos el alma de su madre, y Juan inclinando su cabeza sobre el pecho de María.

Entre los interesantes frescos de la iglesia de la Transfiguración, en el monasterio de Spas-Mirozhsky en Pskov (Rusia), ${ }^{120}$ fechables antes de $1156,{ }^{121}$ la Koimesis ${ }^{122}$ presenta una composición en rígida simetría (Fig.9). Tras el lujoso lecho de María, de bordadas telas, Cristo eleva el alma de su madre (recién nacido envuelto en mantillas) hacia su izquierda, flanqueado por dos arcángeles, que le hacen guardia de honor cubiertos con vestimentas cortesanas, mientras otros dos ángeles revolotean sobre el Salvador con las manos veladas por grandes paños. Los apóstoles y tres obispos, con su vestimenta eclesiástica característica, se concentran en dos grupos a ambos extremos de la cama, con Pedro batiendo un incensario en la cabecera, en balance con el grupo de discípulos a los pies de María, encabezado por el reverente Pablo, en tanto que el encanecido Juan se inclina sobre el pecho de la Virgen. Culminando la fuerte simetría en ambos extremos del fresco, dos edificios albergan cada uno sendas mujeres quejumbrosas.

Entre los frescos en la iglesia de la Panagia Arakiotissa (Panagia tou Arakos) en Lagoudera (Chipre), pintados en 1192 con el patrocinio del donante León Autentis, ${ }^{123}$

sobre el mismo tema, por lo cual jugó un papel importante en la difusión de esta escena en Occidente, casi nunca pintada hasta entonces.

118 Velmans comenta al respecto: "Entre las otras grandes festividades [representadas en los mosaicos de la Martorana de Palermo], en la Dormición de la Virgen aflora una sensibilidad nueva. Los apóstoles, inclinados sobre el cuerpo de María, están realmente entristecidos y las dos mujeres, añadidas, hacen gestos elocuentes." (Velmans 1999: 132).

119 Charles Delvoye describe así esta pintura mariana de la Martorana: “A izquierda y derecha se agrupan los apóstoles a los que, según una tradición atestiguada por san Juan Damasceno, se unieron tres santos obispos, reconocibles por su omophorion crucífero: San Dionisio Areopagita, primer obispo de Atenas, Hieroteo y Timoteo, primer obispo de Efeso. A la cabecera san Pedro balancea el incensario. Del otro lado san Pablo apoya la cabeza contra los pies de la Virgen mientras san Juan, hecho ya viejo, posa la suya sobre el lecho de María. Este mosaico se diferencia del de Daphni por la introducción de fondos arquitectónicos según un motivo que se encuentra en miniaturas de la primera mitad del s. XII. Ante el edificio de la derecha aparecen dos mujeres que se lamentan." (Delvoye 1967: 257-258).

${ }^{120}$ Según Velmans (1999: 139), la iglesia del Salvador de la Transfiguración, en el monasterio de Pskov tiene un programa iconográfico particularmente arcaico, aunque con temas nuevos y detalles de vanguardia.

${ }^{121}$ LAZAREv (1967: 227) lo data hacia 1156, y considera estos frescos de estilo similar a los de la iglesia de San Pantaleón de Nerezi. Esa misma fecha defiende Tania Velmans (1999: 139).

122 Repr. en Lazarev 1966: 247, fig. 46.

${ }^{123}$ Según Velmans, "La decoración de la iglesia de la Panagia Arakiotissa (Panagia ton Arakon) en Chipre (1192), ejecutada un año después de la ocupación de la isla por los cruzados, se ha conservado 


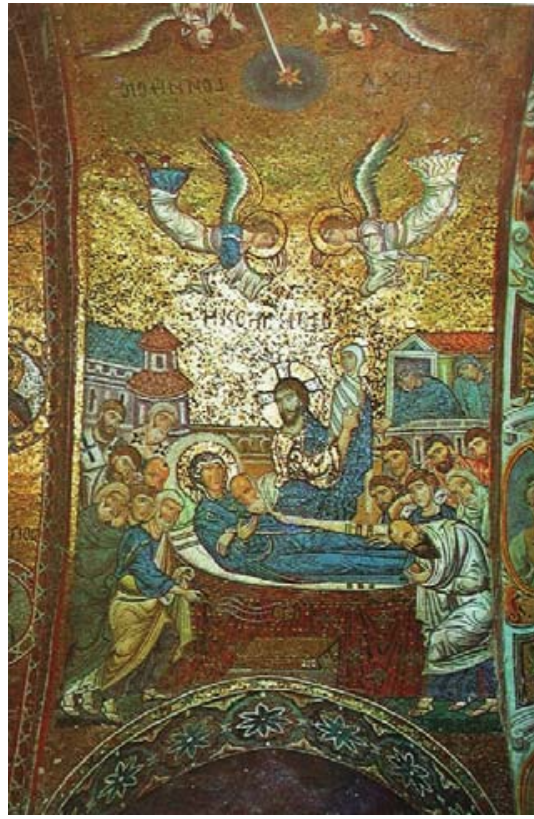

Fig. 8. Dormición de la Virgen, mosaico, 1143-1151, Martorana, Palermo.

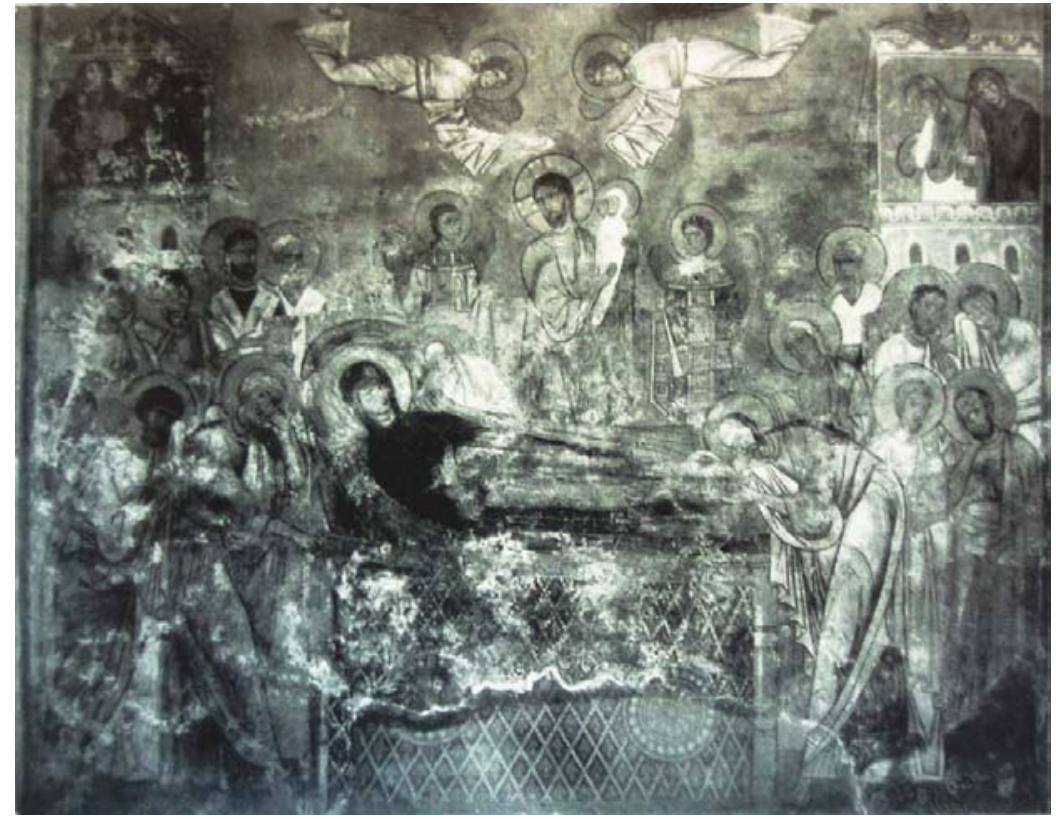

Fig. 9. Koimesis, fresco, antes de 1156, monasterio de SpasMirozhsky, Pskov (Rusia).

la Dormición, plasmada en el luneto oeste, ${ }^{124}$ acentúa un tanto la expresividad de todos los personajes, ${ }^{125}$ incluyendo los tres habituales obispos, revestidos con su omophorion de cruces negras. ${ }^{126}$ Sin embargo, este mural chipriota no aporta ninguna novedad al ya tradicional ordenamiento simétrico de sus personajes y arquitecturas.

\subsection{La Dormición de María en el arte occidental de los siglos X-XII}

\subsubsection{La Dormición en la miniatura occidental}

Durante los siglos X, XI y XII el tema iconográfico bizantino de la Koimesis fue asumido con relativa frecuencia en el Occidente europeo, donde se le adoptó como eficaz estímulo catequético y devocional, aun cuando adaptándolo y reinterpretándolo con no

casi en su totalidad. (...) Entre las grandes festividades, la Natividad muestra a María como una joven dulce y pensativa. Aparece así en casi todas las escenas, con una encarnación fresca, como si a través de su juventud y belleza se buscara conmover al espectador." (Velmans 1999: 173). Esta fecha de ejecución de la Koimesis (1192) es también confirmada por Henry Maguire (1996: 64-65).

124 Repr. en Maguire 1996: 64, fig. 57.

${ }^{125}$ Según Velmans, "Incluso en la Dormición, en el luneto occidental, se le representa [a María] con esa misma frescura en el rostro, mientras que los apóstoles, en cambio, aparecen profundamente apenados. Uno de ellos se oculta el rostro con la mano, san Juan se inclina sobre el pecho de la Theotókos, Cristo rodeado de una mandorla de luz, le mira y lleva su alma bajo la forma de un niño pequeño, en sus brazos." (Velmans 1999: 174).

126 Según Henry Maguire, la inexpresividad y la rigidez de los tres obispos, a uno de los cuales identifica como Santiago, el "hermano" de Jesús, primer obispo de Jerusalén (1996: 64), contrastan con los llorosos y entristecidos apóstoles. (Ibid.: 64-65). 
pocas y significativas variantes. Tales reinterpretaciones occidentales se verificaron, de entrada, en numerosas miniaturas de códices ilustrados y, algo más tarde, si bien con bastante menor asiduidad, en algunos relieves de pórticos o capiteles, $\mathrm{y}$ en ciertos frescos murales. Esos modelos iconográficos orientales se introdujeron en Europa mediante el expeditivo recurso de copiar una y otra vez en los scriptoria monásticos y palatinos los iconos y miniaturas procedentes del entorno bizantino. Como bien apunta Otto Demus, aun existiendo algunos patrones en los manuscritos italianos de la antigüedad tardía, los teólogos y los artistas del monasterio de Reichenau y de otros scriptoria carolingios, responsables de producir manuscritos imperiales, copiaron y adaptaron con avidez las nuevas fórmulas iconográficas bizantinas de la vida de Cristo. ${ }^{127}$ Ahora bien, lo afirmado por Demus sobre los scriptoria carolingios resulta extrapolable a otros scriptoria occidentales altomedievales, situados más allá de los estrictos límites temporales y territoriales del específico ámbito carolingio.

Como era previsible, en esas miniaturas occidentales subsidiarias las versiones de la Dormición adoptaron sin ambages la estructura sencilla y sintética que ya observamos en sus homólogos antecedentes bizantinos (iconos y miniaturas). Semejante simplificación compositivo-narrativa de la Koimesis se observa en la mayoría de las iluminaciones miniadas occidentales, como, por ejemplo, en las Dormiciones del Benediccional de Saint Aethelwold, (975-980), de la British Library de Londres, ${ }^{128}$ el Pontifical del arzobispo Robert (c. 980-990, bastante similar al de Aethelwold), en la Bibliothèque Municipale de Rouen, ${ }^{129}$ el Sacramentario de Verdun, París, ${ }^{130}$ el Evangeliario de Bernulfo (mediados del s. XI), del Museo Arzobispal de Utrecht, ${ }^{131}$ el Evangeliario Prümer de Manchester $\left(2^{\circ}\right.$ cuarto del s. XI), ${ }^{132}$ el libro de Perícopas de San Erentruder (c. 1140), hoy en Munich, ${ }^{133}$ el libro de Perícopas de Bertold de Regensburg $\left(2^{\mathrm{a}}\right.$ mitad s. XI), Nueva York, ${ }^{134}$ el Psalterio de Regensburg-Prüfening en Munich (c. 1180) ${ }^{135}$ o el Antifonario Prümer (s. XII). ${ }^{136}$

127 Demus 1970: 89-90. Como ejemplo de esa práctica occidental de copiar lo bizantino, Demus pone la Dormición del Cod. Lat. 4452, Bayerische Staatsbibliothek, Munich, c. siglo XI.

${ }^{128}$ Dormición de la Virgen, miniatura del Benediccional de San Aethelwold, Londres, British Library, ms Add. 49598, fol. 102v. Repr. en ThÉREL 1984: s.p., pl. VIII, fig. 11; en SCHILLER 1980, Band 4,2: 354, fig. 604.

129 Tránsito de la Virgen, miniatura del Pontifical del arzobispo Robert (c. 980-990), Rouen, Bibliothèque Municipale, fol. 54v. Repr. en color en BANGo ToRviso 2003: 219, fig. 208. Esta miniatura de Rouen, hecha en el scriptorium de Winchester, es muy similar por su estructura y decoración a la del Benediccional de San Aethelwold (producida en el mismo scriptorium), pero, a diferencia de ésta última, sólo representa a la Virgen en su lecho con cuatro mujeres (no tres) a su alrededor, obviando además la representación de los apóstoles y los ángeles.

${ }^{130}$ Dormición de la Virgen, miniatura del Sacramentario de Verdun, París, Bibliothèque Nationale, ms lat. 18005, fol. 118v. Repr. en Thérel 1984: s.p., pl. IX, fig. 14.

${ }^{131}$ Repr. Toscano 1960, vol. 2: 182, fig. 150; en Schiller 1980, Band 4,2: 352, fig. 599.

132 Repr. en SCHILLER 1980, Band 4,2: 353, fig. 602.

${ }^{133}$ Repr. En Ibid.: 353, fig. 603.

${ }_{134}$ Repr. en Ibid.: 353, fig. 601.

${ }_{135}$ Repr. en Ibid.: 357, fig. 612.

${ }^{136}$ Repr. en Ibid.: 355, fig. 607. 
Todas estas imágenes en códices iluminados europeos exhiben la misma estructura convencional de los marfiles bizantinos. María yace sobre su lecho en posición horizontal, paralela al borde inferior de la lámina, salvo en el Evangeliario de San Erentruder, mientras - contrariando la clásica postura bizantina - la cabecera de la cama se orienta hacia la izquierda del cuadro, salvo en el Troparium et Sequentarium de Bamberg, así como en el libro renano de Perícopas de París, en cuyas escenas del tránsito y los funerales la cabecera del lecho se orienta hacia la derecha del folio.

Como en las Koimesis bizantinas, también en estas miniaturas occidentales Cristo casi siempre se yergue en el centro, tras el lecho mortuorio, en actitud de recibir entre sus brazos y elevar hacia su izquierda el alma de su progenitora. Sin embargo, hay no pocas excepciones a esta convención, tal como se aprecia en las dos escenas del libro renano de Perícopas de París: en la escena del tránsito de este códice parisino, Cristo aparece de medio cuerpo en lo alto de un semicírculo (el cielo), extendiendo los brazos para recibir el alma mariana, que le ofrecen dos ángeles, erguidos sobre el suelo, conforme a un planteamiento opuesto a la tradición apócrifa y a la iconografía bizantina; en la subsiguiente escena de los funerales, Cristo se muestra en el mismo arco de círculo, pero asumiendo ahora la forma de un estático e inexpresivo busto. Por otra parte, en el Devocional de San Aethelwold (Fig.10) y en el Troparium et Sequentarium de Bamberg la persona de Cristo, en lugar de manifestarse palmariamente mediante su cuerpo entero, se sugiere apenas mediante una mano abierta, que, en el borde superior del cuadro, emerge de un nimbo luminoso, dispuesta a recibir el espíritu de María en su subida al cielo.

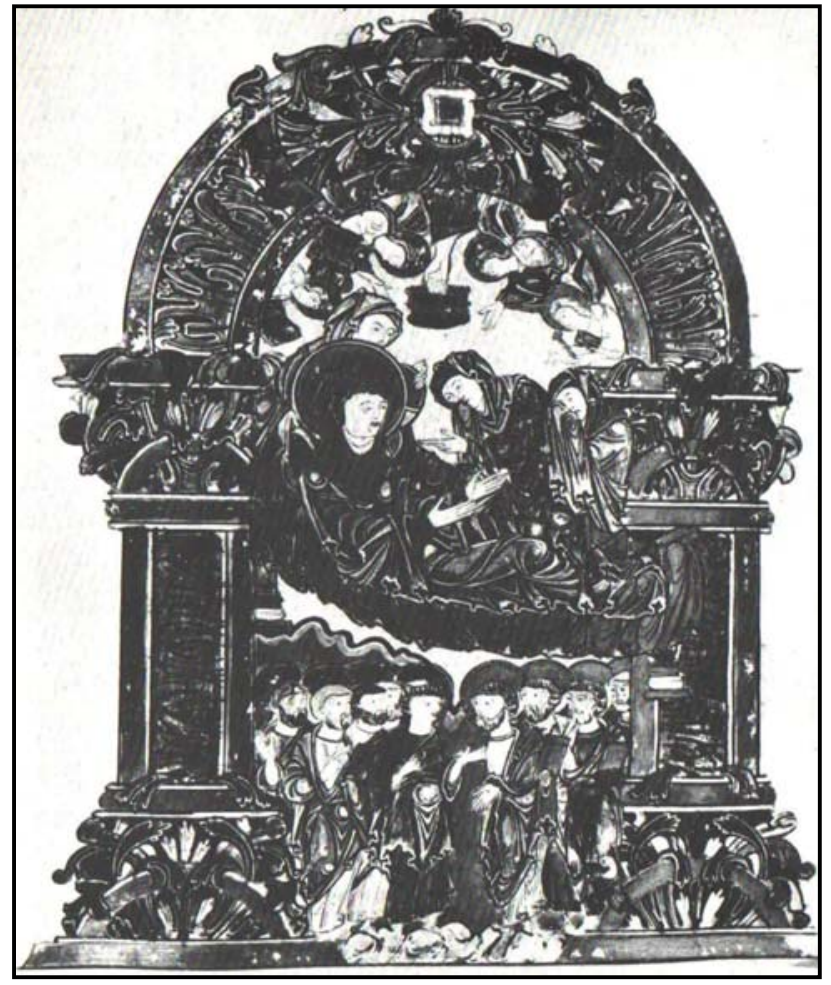

Fig. 10. Dormición de María, miniatura, Benediccional de Saint Aethewold, 975-980. British Library, Londres.

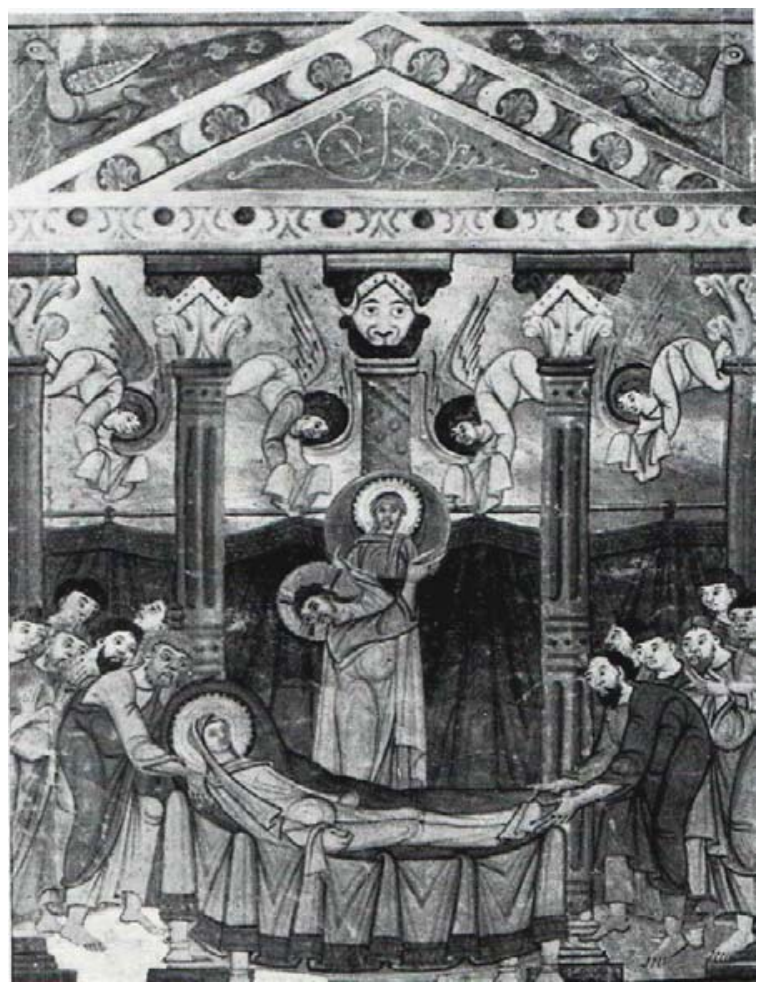

Fig. 11. Dormición de María, miniatura, Evangeliario de Bernulfo, Reichenau-Umkreiss, med. s. XI, Museo Arzobispal, Utrecht. 
En estas miniaturas occidentales el alma de la Virgen se representa a menudo bajo el convencional aspecto de un neonato fajado o envuelto en mantillas, casi siempre de mayor tamaño que en sus homólogos bizantinos, si bien no pocas veces se manifiesta bajo la forma de un busto de mujer más o menos desarrollada (como en el Sacramentario de Verdun, en el Evangeliario de Bernulfo (Fig.11), en las Perícopas de San Erentruder, en el Evangeliario de la catedral de Padua, en el Troparium et Sequentarium de Bamberg y en el libro de Perícopas del emperador Heinrich II), o incluso bajo la apariencia de una mujer adulta, a escala reducida (como se aprecia en el Salterio de Regensburg-Prüfening y en el libro renano de Perícopas de París).

En las miniaturas occidentales, el número, la ubicación y las actitudes de los apóstoles no siempre responden al canon bizantino. Cierto es que algunas imágenes miniadas occidentales conservan muchos de los elementos esenciales del consabido modelo de Bizancio, en especial, su distribución en dos grupos simétricos de seis individuos (aun desechando, por lo general, las poses y las acciones de Pedro, Pablo y Juan), como se observa en el Evangeliario de Bernulfo, el Sacramentario de Verdun, el Evangeliario Prümer (Fig.12), el Troparium de Bamberg, el Evangeliario de Padua y el libro de Perícopas de Heinrich II (Fig.13). Sin embargo, en muchos otros casos el número de apóstoles se restringe drásticamente, hasta casi desaparecer, su distribución en el espacio se verifica sin orden preestablecido y se abandona el prurito de la simetría, tal como se aprecia en el Benediccional de San Aethelwold, en el libro de Perícopas de San Erentruder, en el libro de Perícopas de Bertold de Regensburg, en el Salterio de Regensburg-Prüfening y en el libro renano de Perícopas de París.

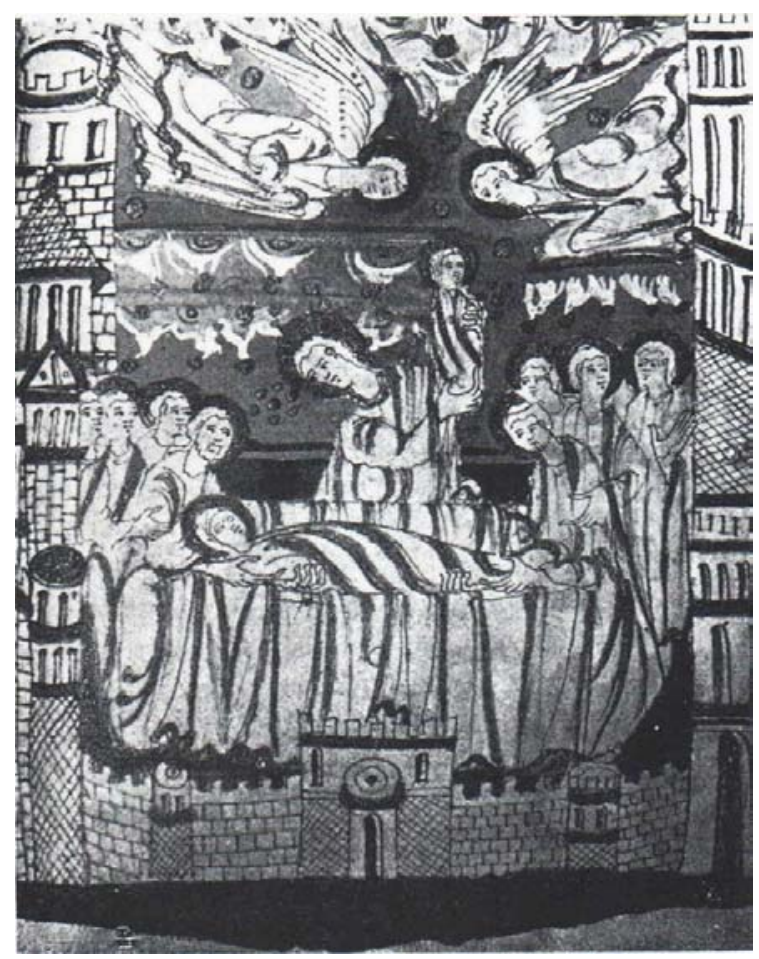

Fig. 12. Dormición de María, miniatura, Evangeliario Prümer, $2^{\circ}$ cuarto s. XI, Manchester.

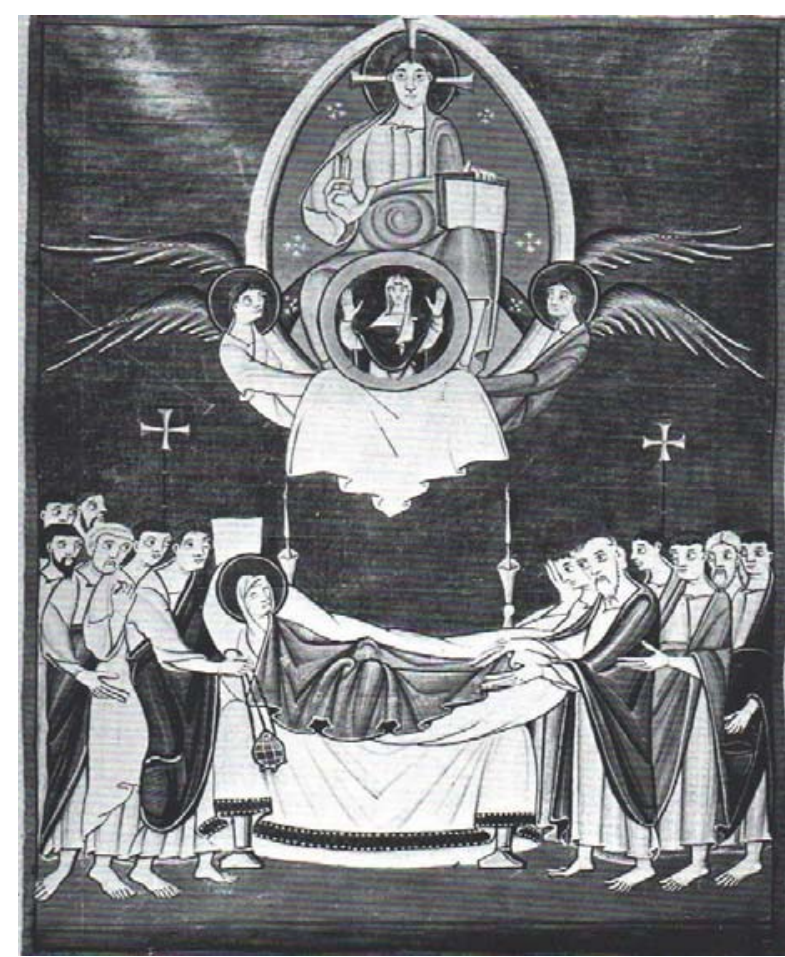

Fig. 13. Dormición de María, miniatura, Perícopas de Heinrich II, c. 1007-1012. Bayerische Staatsbibliothek, Munich. 
Por si fuera poco, en las iluminaciones occidentales las actitudes de los apóstoles resultan más estáticas e inexpresivas que en el arte bizantino, hasta el punto de abandonar casi siempre los tradicionales gestos de Pedro, Pablo y Juan, abrazando la cabeza o los pies de María, reclinándose sobre su pecho, balanceando el incensario, llevando la palma, entonando salmodias o portando la litera o el cuerpo de María. Únicas excepciones a semejante pasividad apostólica son las que exhiben el Sacramentario de Verdun, el libro de Perícopas de Heinrich II y el libro renano de Perícopas de París (escena del funeral), en los cuales se observa a Juan balanceando un incensario y a otros apóstoles portando cruces procesionales, mientras, en el caso de Verdun, uno de los discípulos lleva un hisopo en su vasija de agua bendita.

Análoga modificación experimentan los ángeles en las miniaturas occidentales. Salvo el libro de Perícopas de Bertold de Regensburg, donde sólo aparece un ángel, y el libro renano de Perícopas de París, donde ninguno de ellos asiste al funeral de la Virgen, en casi todas las iluminaciones miniadas occidentales se presentan dos, cuatro o seis ángeles, volando casi siempre en simetría, aun si a veces revolotean en desinhibido desorden (Perícopas de San Erentruder y Antifonario Prümer) o incluso permanecen en pie sobre el suelo (libro renano de Perícopas de París, en la escena de la muerte).

Al margen del ineludible lecho, féretro o sarcófago (según los casos), desaparece por entero el mobiliario doméstico y la escenografía urbano-arquitectónica en la mayoría de estas miniaturas occidentales: conservan, no obstante, semejante escenografía las relativamente similares dormiciones de los Evangeliarios de Bernulfo y de Padua (alojadas bajo una construcción "clásica", apeada sobre columnas y coronada con frontón triangular), el Benediccional de San Aethelwold (enmarcada por un pesado arco de medio punto), el libro de Perícopas de Bertold de Regensburg (cuyo tránsito/entierro se escenifica bajo un vasto arco de medio punto, rematado por tres sugestivos edificios turriformes) y, de modo muy sobresaliente, el Evangeliario Prümer (cuya Dormición se halla circundada por murallas y construcciones torreadas, las cuales identificarían primordialmente a la Jerusalén terrestre, donde sucede el tránsito de la Virgen, pero que, en segunda instancia, podrían constituir también una referencia simbólica a la Jerusalén celeste, hacia donde Jesús conduce, por medio de sus ángeles, el alma de su madre).

\subsubsection{La Dormición de María en el arte monumental de Occidente}

Por comparación con la rica complejidad compositiva, la profundidad simbólico-doctrinal y la extensa difusión cronológica y territorial de las representaciones murales de la Koimesis en el entorno bizantino, las imágenes monumentales de la Dormición en el Occidente europeo exhiben, por el contrario, extrema simplicidad estructural, notoria pobreza significante y muy escasa propagación en el tiempo y en el espacio. De hecho, fuera de las obras murales (sobre todo, mosaicos) hechas en Italia por artistas bizantinos o bizantinizantes, como las insertas en la ya analizada iglesia de la Martorana en Palermo, no se conocen en la Europa de los siglos X-XII pinturas parietales significativas sobre el tránsito de María: sirve apenas de excepción a esta regla un simplicísimo fresco 
con este motivo mariano (c. 872-882) en la iglesia de Santa María Egipcíaca en Roma, construida sobre la estructura del templo romano de Portuno. ${ }^{137}$

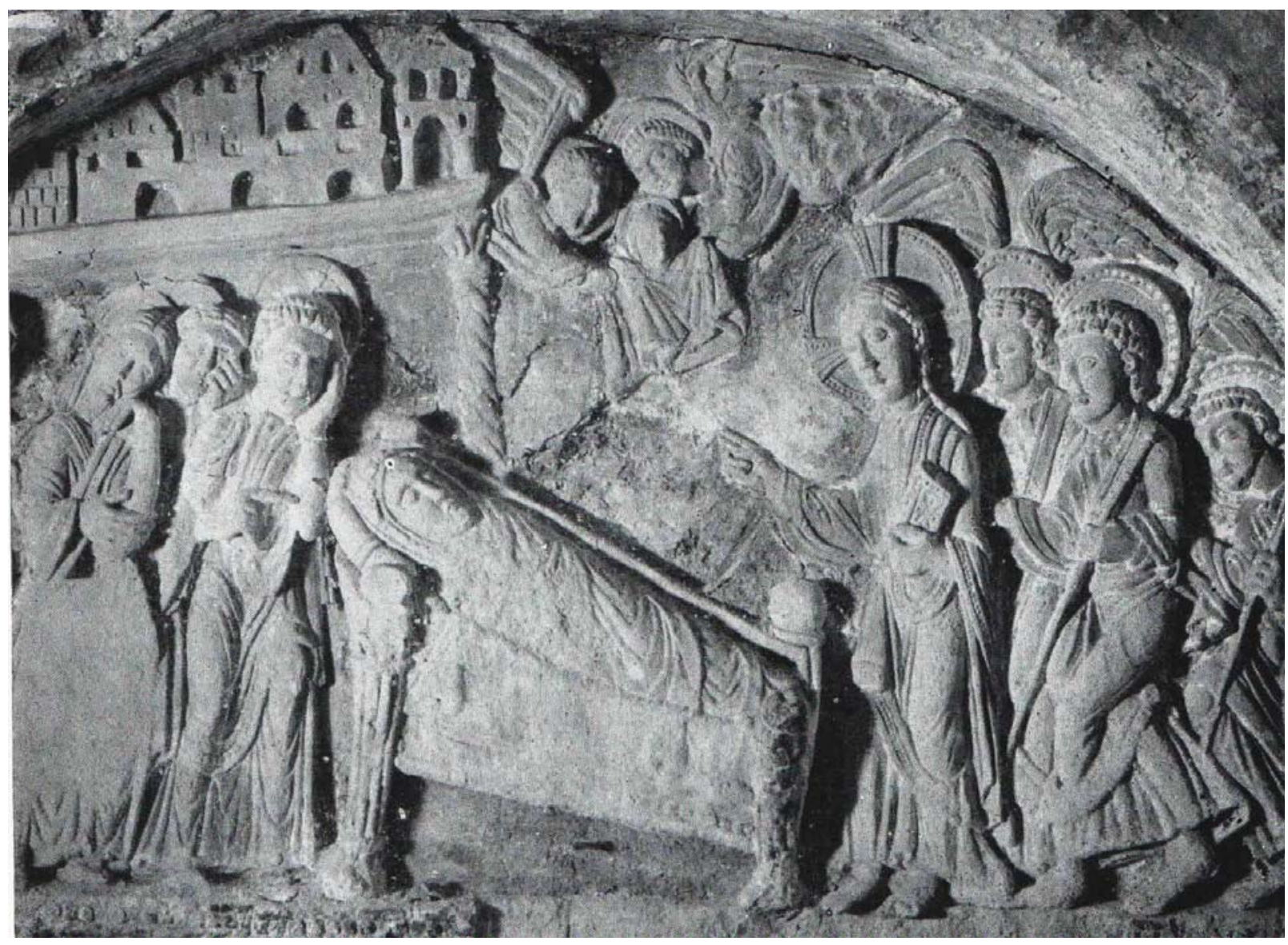

Fig. 14. Dormición de María, estuco, s. X. San Pietro al Monte, Civate.

Con un resultado algo más reconfortante, al menos cinco ejemplos de imágenes escultóricas de la Dormición de María en iglesias de Italia y Francia vienen a compensar en alguna medida el gran vacío pictórico europeo sobre el tema bajo análisis. Destaca, de entrada, por su antigüedad (siglo X) un relieve en estuco en el templo de San Pietro al Monte en Civate (Lecco, Italia) (Fig.14), que representa el momento supremo en que Cristo acude junto a la ya fallecida Virgen para llevarse su cuerpo amortajado, dispuesto sobre la cama en dinámica oblicuidad: ${ }^{138}$ rodeado por dos grupos de apóstoles entristecidos, Jesús, a los pies del lecho funerario, bendice a su madre con la mano derecha, sosteniendo en su izquierda un libro cerrado; dos ángeles, revoloteando en el sector derecho sobre Cristo y la difunta, trasladan ya hacia el cielo en sus manos veladas el alma mariana, representada como una cabecita de niña; el fondo del sector izquierdo lo colma una somera escenografía arquitectónica, denotativa de la casa jerosolimitana de María y de la propia ciudad de Jerusalén.

137 Repr. en Schiller 1980, Band 4,2: 377, fig. 657.

138 Repr. Toscano 1960, vol. 2: 212, fig. 180; en Schiller 1980. Band 4,2: 362, fig. 624. 
Interesantes son también dos relieves del siglo XII, muy similares por la composición y complementarios por el concepto, esculpidos en la cantoría de la Abadía de Santa María en Vezzolano (Piamonte, Italia): el primero de ellos, dedicado al entierro de María, ${ }^{139}$ presenta a los doce apóstoles, dispuestos en arco de círculo, en el momento de introducir a la Virgen en el sarcófago, con expresiones de pena contenida; el segundo relieve, dedicado a la subsiguiente resurrección y asunción corporal de la Madre de Dios, ${ }^{140}$ plasma la escena en que los ángeles, tras despertar a María del sueño de la muerte, comienzan a levantar su cuerpo para conducirlo al paraíso

El tímpano de la iglesia parroquial de Notre-Dame-des-Anges en Cabestany (Roussillon, Francia), datado en la $2^{\mathrm{a}}$ mitad del siglo XII, ${ }^{141}$ representa en una apretada estructura diversos episodios del tránsito de la Virgen: en la esquina izquierda se aprecia su resurrección por obra de Cristo; en el ángulo derecho se observa su asunción corporal al cielo, conducida por los ángeles en una mandorla; en el centro del tímpano el Redentor, en actitud de bendecir con un libro abierto en la mano, se hace acompañar por su madre, efigiada en la clásica pose de la Virgo Orans, en clara referencia a su Asunción en cuerpo y alma al cielo.

El tímpano del pórtico oeste de la catedral de Notre-Dame en Senlis (Oise, Francia),${ }^{142}$ c. $1170,{ }^{143}$ cuya parte central ocupa la entronización de María en el cielo, tiene en su registro inferior (dintel) dos escenas complementarias: a la izquierda (muy deteriorado), el entierro de la Madre de Dios, con los apóstoles en actitud de introducir su cadáver en el sarcófago, mientras dos ángeles en vuelo trasladan su alma infante al cielo; ${ }^{144}$ a la derecha, la resurrección de la Virgen, ${ }^{145}$ con seis afanosos ángeles, de dinámico accionar, ocupados en levantar y conducir al cielo el cuerpo resucitado de la Deipara.

Por último, el tímpano procedente de la iglesia de Saint-Pierre-le-Puellier, c. 1175, hoy en el Museo de Bourges ${ }^{146}$ (Fig. 15), se divide en dos registros, separados por una pesada estructura arquitectónica, articulada por arcos de medio punto: el registro inferior -con mucho, el más extenso, aunque hoy muy destruido - se dedica a diversos episodios de la Dormición de María; ${ }^{147}$ el registro superior se subdivide, a su vez,

\footnotetext{
139 Repr. en Toscano 1960, vol. 2: 206, fig. 174.

140 Repr. en Ibid.: 214, fig. 182.

141 Repr. en Therel 1984: s.p., pl. XII, fig. 21.

142 Repr. en Ibid.: s.p., pl. I, fig. 1.

143 Aunque considerado de estilo protogótico, asumimos aquí este tímpano de Senlis (c. 1170), por estar dentro del lapso cronológico de los siglos X-XII que nos hemos fijado en este artículo.

144 Repr. en Schiller 1980, Band 4,2: 365, fig. 629; en Therel 1984: s.p., pl. I, fig. 1.

145 Repr. en Schiller 1980, Band 4,2: 364, fig. 627; en Therel 1984: s.p., pl. I, fig. 1; en Toscano 1960, vol. 2: 208, fig. 176 (escena de ángeles llevándose el cuerpo de María).

146 Repr. en Schiller 1980, Band 4,2: 362, fig. 625.

147 Marie-Louise Thérel analiza así el sector inferior de este tímpano: "Les images groupées en deux registres, sur le bas-relief de Saint-Pierre-le-Puellier, illustrent le récit d'un transitus: le pseudoMéliton vraisemblablement; leur signification est explicitée par des inscriptions gravées tout autour du monument. Sous un complexe architectural qui évoque une église en coupe longitudinale, deux personnages se tiennent debout, à l'angle inférieur gauche; cette scène est désignée par l'inscription: PALMAM VICTRICI FERT ANGELVS: elle représente la remise du brabéion par l'archange Michel à Marie. L'image centrale, disposée sous les six arcades du monument, a été mutilée, mais les personnages
} 
en dos escenas, que figuran el entierro de la Virgen, a la izquierda, y, a la derecha, su asunción corporal al cielo, envuelta en una mandorla, que impulsan dos grandes ángeles voladores. ${ }^{148}$

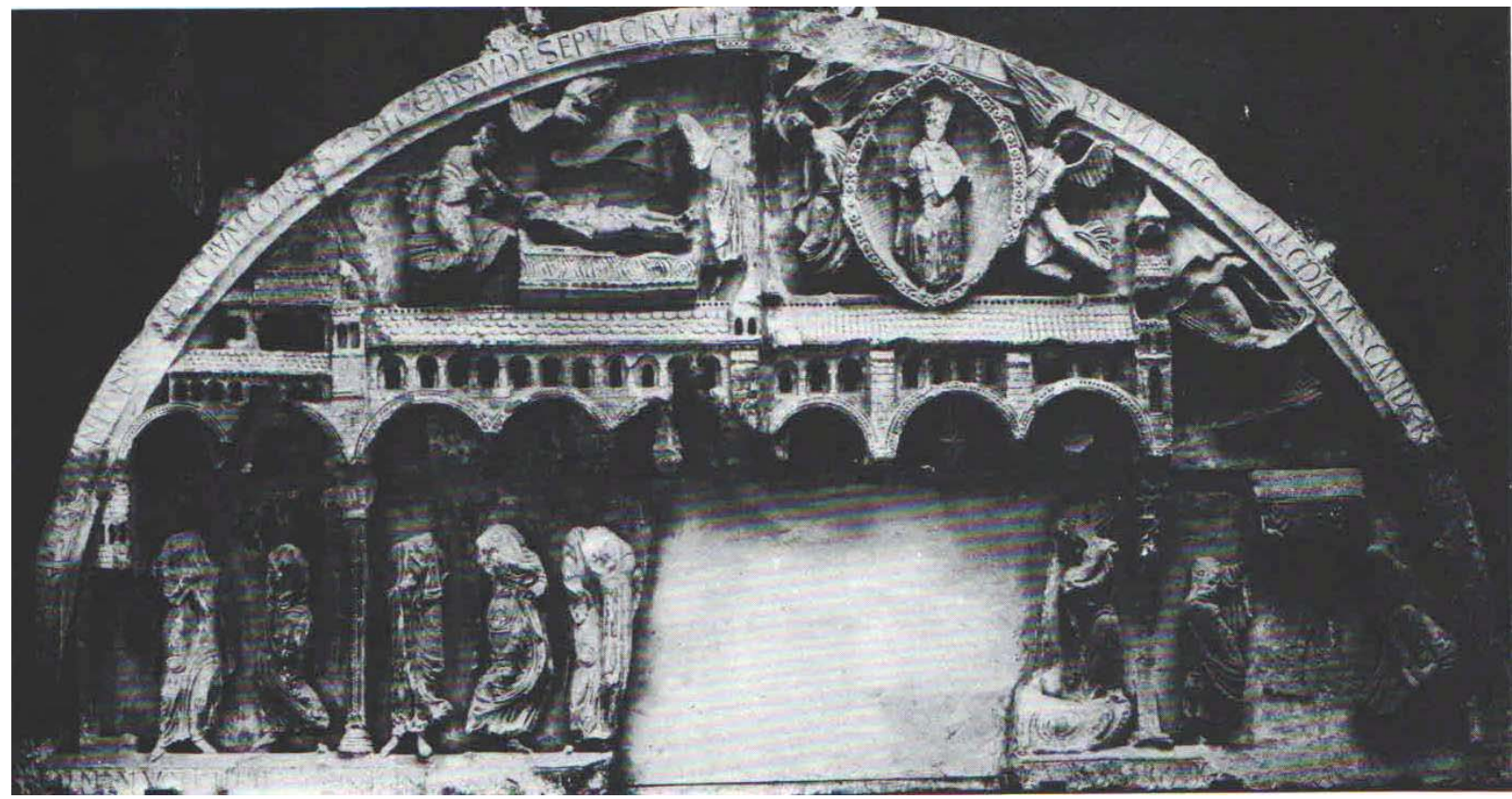

Fig. 15. Tránsito de María, tímpano procedente de la iglesia de Saint-Pierre-le-Puellier, c. 1175, Museo de Bourges.

\section{Análisis iconográfico de las Dormiciones de los siglos X-XII}

Tras este largo recorrido por textos e imágenes, hora es ya de poner en luz las incidencias directas que los tres escritos apócrifos ya mencionados podrían haber ejercido sobre las imágenes bizantinas y occidentales de la Dormición aquí analizadas, con-

conservés aux extrémités permettent d'identifier la scène et de rétablir l'inscription qui la désigne: HIC GENITRI(cis) DEs(ide)RATUs (animam) MATRIS DEI FERT. Elle représentait donc la Dormition de Marie. Deux personnages, à gauche, s'avancent vers un troisième, Jean peut-être, qui accueille les apôtres et les introduit dans la chambre auprès du lit de Marie dont on aperçoit, à droite, la partie inférieure du corps. Debout au pied de ce lit, un ange tend ses mains voilées pour recevoir, des mains du Christ, l'âme de la Vierge. Le dernier compartiment de ce registre représente le transport, par deux apôtres, du cercueil de la Vierge pareil à une châsse, au-dessus duquel un ange, ailes déployées, figure « les milices angéliques portées par les nuées ». La trace d'une silhouette évoque le geste de Jéphonias essayant de renverser ce cercueil." (THÉREL 1984: 58-59).

${ }^{148}$ Marie-Louise Thérel describe así el sector superior del tímpano de Sain-Pierre-le-Puellier: "Deux scènes se partagent le sommet du tympan: à gauche, l'ensevelissement de Marie par deux apôtres tandis qu'un ange encense le corps de la Vierge; à cette image correspond l'inscription: IMPONITVR PVLCHRVM CORPVS SINE FRAVDE SEPVLCRVM. Enfin, à droite, Marie est emportée au ciel dans une gloire par deux anges. Deux inscriptions, l'une sur le bord droit de la base du tympan, l'autre au-dessus de cette image, précisent le sens de cette scène: CORPVS MATRIS DEI FERTVR AD COELVM ET IESVS AD PATREM FECIT ALMAM SCANDERE MATREM. Il s'agit donc bien de l'assomption corporelle de la Vierge." (Thérel 1984: 59). 
forme al propósito de tratar de mostrar que los detalles descriptivos de los diversos cuadros reflejan de manera explícita uno u otro de los pormenores narrativos de dichos apócrifos. En ese orden de ideas, podemos sin temor afirmar que cada elemento iconográfico de esa persistente estructura narrativa exhibida en las obras de arte elegidas se inspira directamente en las fuentes apócrifas o en algún comentario teológico derivado de ellas, tal como intentaremos poner de relieve a continuación.

En el marco del convencional ordenamiento iconográfico de las Koimesis altomedievales, sobresale en primera instancia la situación de María, quien, cubierta por entero con vestidos oscuros, suele yacer (casi siempre con los ojos cerrados) sobre un lujoso lecho funerario, ornado con ricas telas bordadas o recamadas. Todo ello sintoniza con lo que indica el Ps. José de Arimatea: "Tunc beata Maria lavit se et induit se sicut regina et exspectabat adventum filii sui, sicut promiserat ei." 149

La actitud de los apóstoles rodeando el lecho de la Virgen obedece al cumplimiento de la promesa hecha por Jesús a su madre, a ruego expreso de ésta, en el sentido de verse acompañada durante su tránsito por su propio hijo, para hacerse cargo personal de su alma, ${ }^{150}$ y por sus doce discípulos, para custodiarla, despedirla y reconfortarla. ${ }^{151}$ Con ese fin, el Señor, arrebatando a cada uno de los apóstoles, los vivos y los ya muertos bajo el martirio, desde los más lejanos rincones de la tierra, los hizo venir milagrosamente sobre nubes luminosas hasta la casa de María. Así expresa el Ps. Juan el Teólogo la milagrosa presencia de los apóstoles ante el lecho mortuorio de María:

Y el Espíritu Santo dijo a los apóstoles: «Venid todos en alas de las nubes desde los [últimos] confines de la tierra y reuníos en la santa ciudad de Belén para asistir a la madre de Nuestro Señor Jesucristo, que está en conmoción: Pedro desde Roma, Pablo desde Tiberia, Tomás desde el centro de las Indias, Santiago desde Jerusalén. ${ }^{152}$

149 "Luego la bienaventurada (virgen) María se aseó y engalanó como una reina y quedó en espera de la llegada de su Hijo, en conformidad con la promesa de éste.” (Ps. José de ArimateA, V: 643-644).

150 "Entre las muchas cosas que la madre inquirió de su hijo durante el tiempo aquel que precedió a la pasión del Señor figuran las referentes a su tránsito, sobre el cual empezó a preguntarle en estos términos: «¡Oh carísimo hijo!, ruego a tu Santidad que, cuando llegue el momento en que mi alma haya de salir del cuerpo, me lo hagas saber con tres días de antelación; y entonces tú, querido hijo, hazte cargo de ella en compañía de tus ángeles».” (Ps. JosÉ DE ARIMATEA, I: 641).

151 “Después [María] se puso a orar de esta manera: «Señor mío Jesucristo, que por tu extrema bondad tuviste a bien ser engendrado por mí, oye mi voz y envíame a tu apóstol Juan para que su vista me proporcione las primicias de la dicha. Mándame también a tus restantes apóstoles, a los que han volado ya hacia ti y a aquellos que todavía se encuentran en esta vida, de cualquier sitio donde estén, a fin de que, al verlos de nuevo, pueda bendecir tu nombre, siempre loable. Me siento animada porque tú atiendes a tu sierva en todas las cosas»»." (Ps. JuAn el Teólogo, V: 578 ). Por su parte, el Ps. José de Arimatea señala: "Dixit eis beata Maria: "Ego filium meum rogavi, antequam sustineret passionem, ut ipse et vos essetis ad obitum meum; et annuit mihi hoc donum. Unde sciatis quod die crastina erit transitus meus.»." (Ps. José dE ArImATEA, X: 646).

152 Ps. JuAn el TeÓlogo, XII: 581. De la misma manera Juan de Tesalónica, tras señalar que el evangelista Juan se encontraba ya en casa de María, asegura: "Y en el momento mismo en que ellos salieron de la cámara, sobrevino un gran trueno, de manera que todos los presentes fueron presa de la turbación. Y, cuando cesó el ruido del trueno, los apóstoles fueron aterrizando a la puerta de María en alas de las nubes. Venían en número de once, cada uno volando sobre una nube: Pedro el primero y Pablo el segundo; éste viajaba también sobre una nube y había sido añadido al número de los apóstoles, pues el principio de la fe se lo debía a Cristo. Después de éstos se reunieron también los otros apóstoles a las 
Y más adelante este mismo autor completa así el episodio:

También Marcos, vivo aún, llegó de Alejandría juntamente con los otros, [llegados], como se ha dicho, de todos los países. Pedro, arrebatado por una nube, estuvo en medio del cielo y de la tierra sostenido por el Espíritu Santo, mientras los demás apóstoles eran a su vez arrebatados también sobre las nubes para encontrarse juntamente con Pedro. Y así, de esta manera, como queda dicho, fueron llegando todos a la vez por obra del Espíritu Santo. ${ }^{153}$

En casi todas las Dormiciones aquí analizadas los apóstoles rodean, por la cabecera y por los pies, el lecho mortuorio de la Madre del Mesías, en actitud de plegaria y veneración hacia ella, traduciendo así visualmente el relato apócrifo:

Después entramos [los apóstoles] en el lugar donde estaba la madre de nuestro Dios y, postrados en actitud de adoración, le dijimos: "No tengas miedo ni aflicción. El Señor Dios, a quien tú alumbraste, te sacará de este mundo gloriosamente". Y ella, regocijándose en Dios su salvador, se incorporó en el lecho y dijo a los apóstoles: "Ahora sí que creo que viene ya desde el cielo nuestro Dios y maestro, a quien voy a contemplar, y que he de salir de esta vida de la misma manera con que os he visto presentaros a vosotros aquí." 154

O, como lo expresa el tercer autor legendario:

Y, cuando [María] se disponía a preguntarle [a cada apóstol] de dónde venía o por qué causa se había presentado en Jerusalén, he aquí que (de repente) fueron llevados en una nube hasta la puerta de la cámara donde estaba la bienaventurada [virgen] María todos los discípulos del Señor, exceptuado Tomás el llamado Dídimo. Se pararon, pues, y luego entraron y adoraron a la reina, saludándola con estas palabras: "Dios te salve, María; llena eres de gracia; el Señor es contigo". Ella entonces se levantó solícita e, inclinándose, les fue besando y dio gracias a Dios. ${ }^{155}$

En las obras de arte aquí estudiadas, la actitud de los apóstoles es de honda emoción (casi siempre, tristeza y llanto) y devoto recogimiento, reflejando a menudo una actitud de rezo y salmodia, muy a tono con los episodios del fallecimiento, el funeral y el entierro plasmados en ellas, y en plena concordancia con las fuentes apócrifas. Así, el Ps. Juan el Teólogo, tras asegurar que "cuando hubo acabado su oración, [María] dijo a los apóstoles: "Echad incienso y poneos en oración", 156 añade que, al

puertas de María cabalgando sobre nubes. Se saludaron mutuamente y se miraron unos a otros, pasmados al ver cómo habían venido a encontrarse en el mismo sitio. Y dijo Pedro: «Hermanos, hagamos oración a Dios, que nos ha reunido, sobre todo por encontrarse entre nosotros el hermano Pablo». Cuando Pedro hubo dicho estas palabras, se levantaron (todos) en actitud de orar y elevaron su voz diciendo: «Roguemos para que nos sea dado el conocer por qué Dios nos ha congregado». Entonces cada uno hizo reverencia al otro para que orase." (JUAN DE TESALÓNICA, VII: 618-619).

${ }^{153}$ Ps. Juan el Teólogo, XIV: 582.

154 Ps. Juan el TeÓlogo, XV: 582-583.

155 Ps. José de Arimatea, VII: 645.

156 Ps. Juan el Teólogo, XXVI:2006: Juan de Tesalónica (VI: 615), por su parte, afirma: "En 
llegar a la casa de María en Jerusalén, ${ }^{157}$ una vez abandonado el hogar de ésta en Belén, los apóstoles "nos levantamos y estuvimos cantando himnos durante cinco días ininterrumpidamente." 158 No menos explícito es el Ps. José de Arimatea, al indicar que la Virgen solicitó a los discípulos de Jesús:

"Vigilad y orad conmigo para que, cuando venga el Señor a hacerse cargo de mi alma, os encuentre en vela". Entonces dieron todos [los apóstoles] palabra de permanecer vigilantes. Y pasaron toda la noche en vigilia y en adoración, entonando salmos y cantando himnos, acompañados de grandes luminarias. ${ }^{159}$

Ahora bien, aun en las Dormiciones de composición más simple puede detallarse con frecuencia la identidad y la acción de los principales apóstoles, en especial, Pedro, Juan y Pablo. Situado a la cabecera de la cama, se halla siempre Pedro, a veces balanceando de pie un incensario, para significar la ceremonia de los funerales, en otras ocasiones inclinado, tocando con las manos el copete, como queriendo alzar la litera, o abrazando y levantando la cabeza de María, para sugerir el traslado en cortejo fúnebre del cadáver mariano y su entierro en el sepulcro. Esas distintas poses y gestos del sucesor de Cristo responden a algunos pasajes de los apócrifos. Según Juan de Tesalónica, en efecto, luego de tenderse la Virgen en su lecho al terminar su plegaria, "Pedro se sentó a su cabecera y Juan a sus pies, mientras los demás apóstoles rodeaban la cama." 160 Por otra parte, el gesto de Pedro abrazando la cabeza de María puede también representar el pasaje del Ps. Juan el Teólogo, conforme al cual, en el instante mismo de fallecer la Madre de Dios, Pedro, Pablo, Juan y Tomás abrazaron sus pies para sentirse santificados. ${ }^{161}$ Pese a tan explícita afirmación, cabe, sin embargo, precisar que, por las razones que expondremos en seguida, los artistas bizantinos prefieren distribuir esa cercanía de los discípulos predilectos en tres puntos privilegiados del lecho: Pedro en la cabecera, Pablo a sus pies, Juan en el medio y por detrás, reclinando, por lo general, su cabeza sobre el pecho de la Virgen yacente.

La postura de Pedro agitando un incensario se explica por dos motivos esenciales, en íntima relación mutua. Ante todo, responde a la repetida solicitud de María de que

diciendo esto, María llamó a todos cuantos se encontraban junto a ella y les dijo: «Levantaos y orad». Y, después de hacer oración, se sentaron dialogando entre sí sobre las maravillas de Dios y los portentos que había obrado."

157 "Levantáronse, pues, en seguida los apóstoles y salieron de la casa llevando la litera de [su] Señora, la madre de Dios, y dirigiendo sus pasos camino de Jerusalén. Mas al momento, de acuerdo con lo que había dicho el Espíritu Santo, fueron arrebatados por una nube y se encontraron en Jerusalén en casa de la Señora." (Ps. JuAn el Teólogo, XXXII: 590).

158 Ps. Juan el Teólogo, XXXII: 590.

159 "Dixit eis beata Maria: «(...) Vigilate et orate mecum, ut, quando venerit Dominus ad animam meam suscipiendam, vigilantes vos inveniat». Tunc omnes promiserunt se vigilare. Et vigilaverunt et adoraverunt per totam noctem cum psalmodiis et canticis cum magnis luminariis." (PS. JosÉ DE ARimatea, X: 646).

160 Juan de Tesalónica, XII: 630.

161 "Y en el momento de salir su alma inmaculada, el lugar se vio inundado de perfume y de una luz inefable. Y he aquí que se oyó una voz del cielo que decía: «Dichosa tú entre las mujeres». Pedro entonces, lo mismo que yo, Juan, y Pablo y Tomás, abrazamos a toda prisa sus santos pies para ser santificados." (Ps. JuAn el Teólogo, XLV: 597). 
los apóstoles quemasen incienso al aproximarse su tránsito. ${ }^{162}$ Además, ante la enorme dificultad de traducir visualmente la plegaria o el canto de himnos y salmos, la actitud de balancear el incensario es, a nuestro juicio, la manera más eficaz mediante la que el pintor puede visualizar el protagonismo asumido en esos rezos y cánticos por Pedro: no en vano, en su calidad de sucesor de Cristo, él es el sumo pontífice y el celebrante principal del funeral de María ${ }^{163}$ conforme al mandato que le hiciera el propio Mesías. Según el Ps. Juan el Teólogo, en efecto, "Volvióse entonces el Señor y dijo a Pedro: «Ha llegado la hora de dar comienzo a la salmodia». Y, entonando Pedro, todas las potencias celestiales respondieron el Aleluya." 164

Por su parte, Pablo, gracias a su papel de ineludible maestro doctrinal del cristianismo, ${ }^{165}$ adquiere un papel primordial en las Koimesis bizantinas, mediante la significativa actitud de abrazar los pies de la Virgen, sea en gesto de despedida y demanda de santificación, ${ }^{166}$ sea en gesto de conducir el lecho/féretro de María en el proceso del cortejo fúnebre y el entierro. ${ }^{167}$

Más interesantes aún son la postura y la situación del anciano Juan el Evangelista, al que en las Koimesis bizantinas siempre se ve fuertemente inclinado -casi como en prosternación - sobre el cuerpo tendido de María, a menudo apoyando o acercando su cabeza sobre el pecho de ésta. Tan inusual actitud y circunstancia se explicarían, a nuestro entender, por cuatro motivos complementarios: ante todo, por su condición

162 "Y cuando hubo acabado su oración, [María] dijo a los apóstoles: «Echad incienso y poneos en oración»»" (Ps. JuAN El TeÓlogo, XXVI: 587). Este mismo autor confirma en otro pasaje: "En este mismo domingo dijo la madre del Señor a los apóstoles: «Echad incienso, pues Cristo está ya viniendo con un ejército de ángeles»." (Ps. JuAn el TeÓlogo, XXXVIII: 593).

${ }^{163}$ Así lo expresa Juan de Tesalónica: "Y dijo Pedro: «Hermanos, hagamos oración a Dios, que nos ha reunido, sobre todo por encontrarse entre nosotros el hermano Pablo». Cuando Pedro hubo dicho estas palabras, se levantaron (todos) en actitud de orar y elevaron su voz diciendo: «Roguemos para que nos sea dado el conocer por qué Dios nos ha congregado». Entonces cada uno hizo reverencia al otro para que orase. Dícele, pues, Pedro a Pablo: «Pablo, hermano mío, levántate y ora antes de mí, pues me embarga una alegría inenarrable por haber llegado tú a la fe de Cristo». Pablo le dijo: «Dispénsame, Pedro, padre (mío), pues no soy más que un neófito y no soy digno de seguir las huellas de vuestros pies; ¿cómo, pues, voy a ponerme a orar antes que tú? Tú eres, en efecto, la columna luminosa, y todos los hermanos presentes son mejores que yo. Tú, pues, ¡oh padre!, ruega por mí y por todos para que la gracia del Señor permanezca en nosotros». Entonces se alegraron los apóstoles por la humildad de Pablo y dijeron: «Padre Pedro, tú has sido constituido jefe de nosotros; ora tú el primero». Pedro, pues, se puso en oración (...)." (JUAN DE TeSALÓNICA, VII: 619-620).

164 Ps. Juan el Teólogo, XLIV: 596.

${ }^{165}$ Conforme al relato de Juan de Tesalónica, cuando los apóstoles vinieron sobre nubes a Jerusalén, llegaron "Pedro el primero y Pablo el segundo; éste viajaba también sobre una nube y había sido añadido al número de los apóstoles, pues el principio de la fe se lo debía a Cristo." (JuAn DE TesalónICA, VII: 619).

166 Ya vimos antes cómo el Ps. JuAn el Teólogo (XLV: 597) afirmaba que Pedro, Pablo, Juan y Tomás abrazaron los pies de María en el instante de su muerte, para poder ser así santificados. Según este mismo apócrifo, Pablo vino desde Tiberia o la tierra de los Tiberios, una ciudad cercana a Roma. (Ps. Juan el Teólogo, XIX: 588-589).

167 "Y los doce apóstoles, después de depositar su santo cuerpo en el ataúd, se lo llevaron." (Ps. JuAn el Té́logo, XLV: 597). Y Juan de Tesalónica: "Y llevándose los apóstoles el precioso cuerpo de la gloriosísima madre de Dios, señora nuestra y siempre virgen María, lo depositaron en un sepulcro nuevo [allí] donde les había indicado el Salvador.” (JuAn DE TESALÓNICA, XIV: 637-638). 
de "discípulo amado de Jesús", Juan goza del invalorable privilegio de ser el primer apóstol en ser convocado por la Virgen y el primero en acudir a su encuentro en su casa para asistirla durante su tránsito; ${ }^{168}$ además, por esa misma condición, había recibido de Cristo, moribundo en la cruz del Calvario, el encargo de cuidar a María con amoroso esmero; ${ }^{169}$ en tercer lugar, el gesto arrodillado -casi en proskynesis ceremonial - de Juan ante la Madre de Dios puede interpretarse bien sea (según el arzobispo de Tesalónica) como el gesto de imploración del apóstol predilecto, pidiendo al Señor morir él mismo junto con María, para así obtener su protección, ${ }^{170}$ bien sea (según el Ps. José de Arimatea) como la solicitud de perdón que Juan dirige a la moribunda Theotókos por haberla abandonado durante tanto tiempo, y no haberla cuidado como se lo ordenara Jesús desde la cruz en el Gólgota; ${ }^{171}$ por último, es muy significativo el hecho de que los diseñadores de los programas iconográficos y los artistas bizantinos introduzcan en sus Koimesis el gesto de Juan descansando su cabeza sobre el pecho de María, como si quisiesen repetir -en perfecto paralelismo- el precedente gesto del Evangelista reposando su cabeza sobre el pecho de Cristo en la Última Cena. ${ }^{172}$

No podemos pasar por alto el importante detalle de que, según el relato del Ps. Juan el Teólogo, el proceso de la dormición de María, iniciado en su casa de Belén

168 "Y, mientras ella [María] estaba en oración, me presenté yo, Juan, a quien el Espíritu Santo arrebató y trajo en una nube desde Éfeso, dejándome después en el lugar donde yacía la madre de mi Señor. Entré, pues, hasta donde ella se encontraba y alabé a su Hijo; después dije: «Salve, ¡oh madre de mi Señor, la que engendraste a Cristo nuestro Dios!; alégrate, porque vas a salir de este mundo muy gloriosamente»." (Ps. JuAn el Teólogo, VI: 578-579).

169 "Y la santa madre de Dios loó a Dios porque yo, Juan, había llegado junto a si, acordándose de aquella voz del Señor que dijo: «He aquí a tu madre y he aquí a tu hijo»." (Ps. Juan el Teólogo, VII: 579). En ese mismo orden de ideas, Juan de Tesalónica expresa: "Y, mientras se encontraban así charlando, he aquí que se presenta Juan, el apóstol, llamando a la puerta de María. Después abrió y penetró dentro. Pero María, al verlo, sintió turbación en su espíritu y sollozó y lloró, hasta que luego se puso a gritar diciendo a grandes voces: «Juan, hijo mío, no olvides la recomendación que te hizo tu Maestro en relación conmigo cuando yo estuve llorándole junto a la cruz y le dije: Tú te vas, Hijo mío, y ¿a quién me dejas confiada? ¿Con quién habitaré? Y me dijo mientras tú estabas presente y lo oías: Juan es el que te ha de guardar. Ahora, pues, hijo, no eches en olvido las recomendaciones que te fueron hechas por causa mía y acuérdate de que El te hizo a ti objeto de un amor especial entre todos los apóstoles." (JuAN DE TeSAlÓNICA, VI: 615-616).

170 "Cuando oyó decir Juan que iba a salir del cuerpo, cayó de rodillas y dijo entre sollozos: «¡Oh Señor!, ¿quiénes somos nosotros para que nos hayas hecho ver estas tribulaciones? Todavía, en efecto, no habíamos olvidado las primeras, y he aquí que hemos de sufrir otra. ¿Por qué no salgo yo también del cuerpo, para que tú me protejas, oh María?»" (JuAn DE TeSALÓNICA, VI: 617).

171 "El apóstol y evangelista Juan fue trasladado desde Efeso; penetró en la pieza donde se encontraba la bienaventurada [virgen] María y la saludó con estas palabras: «Dios te salve, María; llena eres de gracia; el Señor es contigo». Ella a su vez respondió: «Gracias sean dadas a Dios»; y, levantándose, dio un ósculo a Juan. Después le dijo: «iOh hijo queridísimo!, ¿por qué me has abandonado durante tanto tiempo y no has hecho caso del encargo que te hizo tu Maestro referente a mi custodia, como te mandó mientras estaba pendiente de la cruz?» El entonces, cayendo de rodillas, se puso a pedirle perdón. Y la bienaventurada [virgen] María le bendijo y le besó de nuevo.” (Ps. José de ArimateA, VI: 644).

172 "Recuerda que fuiste el único que pudiste reclinarte sobre su pecho [el de Jesús]. Recuerda que sólo a ti confió su secreto cuando estabas reclinado sobre su pecho, secreto que nadie ha conocido fuera de ti y de mí, ya que tú eres el virgen y (el) elegido. En cuanto a mí, no quiso contristarme, pues vine a ser su habitación. (...) Y El te dio órdenes y tú me lo participaste. Ahora, pues, Juan, hijo mío, no me abandones»." (JUAN DE TESALÓNICA, VI: 616). 
y abruptamente interrumpido por la hostilidad de los judíos, vino a concluir en el hogar de la Virgen en Jerusalén, después de que los apóstoles, trasportándola yacente en su litera para ponerla a salvo, fueran arrebatados en una nube por virtud del Espíritu Santo y conducidos directamente a la casa de María en Jerusalén. Así lo refiere dicho autor:

Levantáronse, pues, en seguida los apóstoles y salieron de la casa llevando la litera de [su] Señora, la madre de Dios, y dirigiendo sus pasos camino de Jerusalén. Mas al momento, de acuerdo con lo que había dicho el Espíritu Santo, fueron arrebatados por una nube y se encontraron en Jerusalén en casa de la Señora. Una vez allí, nos levantamos y estuvimos cantando himnos durante cinco días ininterrumpidamente. ${ }^{173}$

En ese orden de ideas, el pormenor apócrifo de esas nubes luminosas que trasportan a los apóstoles en su inicial venida a Belén y en su posterior huida hacia Jerusalén con la moribunda en su litera se refleja en dos de las obras de arte analizadas. En el fragmento subsistente del icono ( $2^{\mathrm{a}}$ mitad del siglo XI) del Monasterio de Sta. Catalina en el Sinaí, tales nubes parecen quedar plasmadas, en la parte superior izquierda de la tabla, en un alvéolo (el único supérstite, de otros varios probables en el fragmento faltante) en cuyo interior aparecen dos personajes en busto (tal vez un ángel y un apóstol, o quizá dos apóstoles). Más evidente es la plasmación de esas nubes en el fresco de la iglesia de Santa Sofía en Ohrid (c. 1050), en cuyos dos ángulos superiores (hoy bastante difuminados) aparecen sendos alvéolos alargados, alojando cada uno seis apóstoles.

Como ya vimos, las Koimesis bizantinas de los siglos X-XII (no así las occidentales del mismo período) incluyen con frecuencia, junto a los ineludibles apóstoles, a dos o tres santos obispos, revestidos con su distintivo omophorion de cruces negras, tal como se observa en los dos iconos del monasterio de Santa Catalina en el Sinaí, en los frescos de Santa Sofía de Ohrid, de la Panagia Mavriotissa en Kastoria, de la Panagia Phorbiotissa en Asinou, de la Panagia Arakiotissa en Lagoudera, de la iglesia de San Nicolás Kasnitzes en Kastoria y de la catedral del monasterio Mirozshky en Pskov, así como en el mosaico de la Martorana en Palermo. La inclusión de tales obispos en las Koimesis bizantinas responde a la ya citada afirmación de San Juan Damasceno en su segunda homilía sobre la Dormición de María: ${ }^{174}$ haciendo suyo, en efecto, el testimonio del arzobispo Juvenal de Jerusalén, el Damasceno sostiene que, junto con los apóstoles, asistieron también al tránsito de María San Timoteo, primer obispo de Éfeso, San Dionisio Areopagita y San Hieroteo. ${ }^{175}$

No menos importante es la taxativa afirmación de los apócrifos sobre las dos casas de María en Belén y Jerusalén, en las que se inicia y concluye, respectivamente, su muerte. Eso explica por qué muchas de las Dormiciones aquí analizadas insisten en representar en disposición simétrica, a ambos extremos de la escena, sendos edificios o constructos, de variable escala y complejidad. Tales construcciones dobles

${ }^{173}$ Ps. Juan el Teólogo, XXXII: 590.

${ }^{174}$ Véase nuestra Nota 35.

175 SaInt Jean Damascène, Deuxième discours sur l'illustre Dormition de la Toute Sainte et toujours Vierge Marie, 18. En Saint Jean Damascène, Homélies sur la Nativité et la Dormition, op. cit., p. 173. 
no obedecen tanto a los indudables deseos de crear una "escenografía" estéticamente atractiva y de reforzar la casi constante simetría de la composición, cuanto, sobre todo, al deliberado propósito de "recrear" poéticamente el interior y el exterior de las casas betlemita y jerosolimitana de la Virgen en las que acontece su tránsito y su funeral, sin dejar de convertirse, de paso, en sugerente alusión metonímica a toda la aldea de Belén y a la entera ciudad de Jerusalén. Esa directa relación texto/ imagen en lo referente a ambas construcciones simétricas queda patente en muchas de las obras de arte aquí analizadas, a saber, en el fragmento subsistente del icono del Monasterio de Santa Catalina en el Sinaí, en el icono del iconostasio del mismo monasterio sinaítico, en el Evangeliario Prümer de Manchester, en el libro de Perícopas de Bertold de Regensburg, en el Psalterio Regensburg-Prüfening de Munich, en el tímpano de la iglesia de San Pietro al Monte en Civate, en el fresco de la cripta de Hosios Lucas en Fócida, en la iglesia de la Panagia Mavriotissa en Kastoria, en la Panagia Phorbiotissa de Asinou, en la Panagia Arakiotissa de Lagoudera, en la iglesia de San Nicolás Kasnitzes de Kastoria, en la Martorana de Palermo, en la catedral del monasterio Mirozshky en Pskov y en el tímpano de la iglesia de SaintPierre-le-Puellier.

Queda por dilucidar la identidad y el papel que cumplen las mujeres compungidas que, en número de dos o tres, se exhiben a veces asomándose por las ventanas o arcos de los edificios del escenario arquitectónico en algunas Koimesis bizantinas; tal situación se aprecia en el fragmento de icono del monasterio de Santa Catalina en el Sinaí (con tres mujeres en la casa a la derecha, que probablemente tenían un referente análogo en la parte faltante a la izquierda), en los frescos de la Panagia Mavriotissa en Kastoria (con tres damas a la izquierda, y otras dos a la derecha), de la Panagia Phorviotissa en Asinou y del monasterio Mirozshky en Pskov (frescos ambos que plasman dos mujeres en cada una de las dos casas simétricas), así como en el mosaico de la Martorana en Palermo (que sólo incluye dos mujeres en el edificio de la derecha). La inclusión de tales féminas en las Koimesis bizantinas no se explica como un mero recurso estético para "animar" la escena con detalles anecdóticos, ni tampoco - contra lo sostenido por algún experto- como una representación del pueblo judío de Jerusalén. Por el contrario, la maciza presencia de esas mujeres llorosas dentro de los edificios en algunas Dormiciones bizantinas se justifica de plano, por cuanto aquéllas representan a las tres doncellas que, según los relatos concordantes de los tres apócrifos, acompañan a María en su tránsito. Así lo expresa, por ejemplo, el Ps. Juan el Teólogo:

Y, oído esto [el anuncio de su muerte] de labios del santo arcángel, se volvió [María] a la ciudad santa de Belén, teniendo junto a sí las tres doncellas que la atendían. Cuando hubo, pues, reposado un poco, se incorporó y dijo a éstas: "Traedme un incensario, que voy a ponerme en oración". Y ellas lo trajeron, según se les había mandado. ${ }^{176}$

176 Ps. Juan el Teólogo, IV: 577-578. 


\section{No menos explícito es el relato de Juan de Tesalónica:}

Y sobre la hora de tercia sonó un gran trueno desde el cielo y se exhaló un perfume de fragancia (tan suave), que todos los circunstantes fueron dominados por el sueño, exceptuados solamente los apóstoles y tres vírgenes, a quienes el Señor hizo velar para que dieran testimonio de los funerales de María y de su gloria. ${ }^{177}$

Por si fuera poco, el Ps. José de Arimatea nos precisa la identidad de esas tres doncellas amigas y servidoras de María, al decir que ésta, presintiendo cercana su muerte, "rogó a todos sus parientes que la guardaran y le proporcionaran (algún) solaz. Tenía a su lado tres vírgenes: Sófora, Abigea y Zael."178

Desde cualquier perspectiva por donde se lo considere, el elemento más destacable en las Dormiciones altomedievales bizantinas y occidentales es, sin duda, Cristo, plasmado casi siempre de pie en actitud de recibir entre sus brazos, levantándola hacia el cielo, el alma de su madre, alma mariana efigiada bajo la apariencia de un recién nacido envuelto en fajas o mantillas. Todo ello traduce al pie de la letra el relato unánime de los apócrifos en estudio. Según esas tres leyendas, sentado sobre un trono de querubines, Cristo desciende del paraíso celestial, escoltado por innúmeros ejércitos de ángeles, arcángeles, serafines y potestades, ${ }^{179}$ para recibir el alma de su madre, ${ }^{180}$ conforme a una promesa que Él le hiciera. ${ }^{181}$ Semejante promesa es narrada así el el Ps. José de Arimatea:

El [Jesús], por su parte, acogió la súplica de su madre querida y le dijo: “iOh habitación y templo del Dios vivo, oh madre bendita, oh reina de todos los santos y bendita entre todas las mujeres! (...) ¿Cómo voy a abandonarte después de haberme gestado y alimentado, después de haberme llevado en la huida a Egipto y haber sufrido por mí muchas angustias? Sábete, pues, que mis ángeles siempre te guardaron y te seguirán guardando hasta el momento de tu tránsito. Pero (...), cuando me vieres venir a tu encuentro en compañía de los ángeles y de los arcángeles, de los santos, de las vírgenes y

177 JuAn de TeSAlÓNicA, XII: 630.

178 Ps. José de Arimatea, V: 644.

179 El Ps. Juan el Teólogo escribe: "Y, mientras ellos [los apóstoles] oraban, se produjo un trueno en el cielo y se dejó oír una voz terrible, como [el fragor de] los carros. Y en esto [apareció] un nutrido ejército de ángeles y de potestades y se oyó una voz como [la] del Hijo del hombre. Al mismo tiempo, los serafines circundaron en derredor la casa donde yacía la santa e inmaculada virgen y madre de Dios." (Ps. Juan el Teólogo, XXVI: 587). A su vez, Juan de Tesalónica enuncia: "Y he aquí que (de repente) se presenta el Señor sobre las nubes con una multitud sin número de ángeles. Y Jesús en persona, acompañado de Miguel, entró en la cámara donde estaba María, mientras que los ángeles y los que por fuera rodeaban la estancia cantaban himnos." (JuAn DE TESALÓNICA, XII: 630).

180 "Adveniente die dominica, hora tertia, (...) descendit Christus cum multitudine angelorum et accepit animam suae matris dilectae.” (Ps. JosÉ DE ARIMATEA, XI: 647).

181 "María entonces abrió su boca y dio gracias con estas palabras: «Te bendigo porque no me has desairado en lo que se refiere a tu promesa. Pues me diste palabra reiteradamente de no encargar a los ángeles que vinieran por mi alma, sino venir tú (en persona) por ella. Y todo se ha cumplido en mí, Señor, conforme a tu ofrecimiento. ¿Quién soy yo, pobrecita de mí, para haberme hecho digna de tan gran gloria?» Y al decir estas palabras llenó su cometido, mientras su cuerpo sonreía al Señor.” (JUAN DE TESAlÓNICA, XII: 630-631). 
de mis discípulos, ten por cierto entonces que ha llegado el momento en que tu alma va a ser separada del cuerpo y trasladada por mí al cielo, donde nunca ha de experimentar la más mínima tribulación o angustia». ${ }^{182}$

Varios siglos antes, el Ps. Juan el Teólogo expresaba así el cumplimiento de esa promesa mesiánica:

Y en el mismo momento se presentó Cristo sentado sobre un trono de querubines. Y, mientras todos nosotros estábamos en oración, aparecieron multitudes incontables de ángeles, y el Señor [estaba] lleno de majestad sobre los querubines. Y he aquí que se irradió un efluvio resplandeciente sobre la santa Virgen por virtud de la presencia de su Hijo unigénito, y todas las potestades celestiales cayeron en tierra y le adoraron. ${ }^{183}$

La persistente referencia de los apócrifos a las cohortes angélicas que acompañan a Cristo en su descenso junto al lecho de su madre explica por qué, en todas las imágenes de la Dormición en los siglos X-XII, hay siempre algunos ángeles o arcángeles que revolotean por el cielo o permanecen firmes, como guardia de honor, a la vera del Mesías.

Siempre según el relato del trío de apócrifos ya referidos, tras un diálogo de reconforto y despedida entre María y su hijo, ${ }^{184}$ en el trascurso del cual éste le confirma el traslado de su alma y su cuerpo al cielo, ${ }^{185}$ "el Señor, después de extender sus puras manos, recibió su alma santa e inmaculada." ${ }^{186}$ Al sobrevenir el tránsito de la Virgen, Cristo envuelve su alma en unos resplandecientes velos, y se la entrega al arcángel Miguel para que la lleve al cielo, ${ }^{187}$ mientras los ángeles entonan cánticos celestiales y se expande por la casa un resplandor indescriptible y un suave perfume. ${ }^{188}$

182 "Tum suscepit deprecationem dilectae matris dixitque ei: "O aula et templum Dei vivi, o puerpera benedicta, o regina omnium sanctorum et benedicta super omnes feminas (...). Quomodo te deseram postquam tu me portasti et nutristi, fugiendo in Aegyptum detulisti et multas angustias pro me sustinuisti? Ecce scias quia angeli mei semper custodierunt te et custodient usque ad transitum tuum. Sed (...) cum videris me cum angelis et archangelis, cum sanctis et cum virginibus et cum meis discipulis ad te venientem, scito pro certo quod anima tua separabitur a corpore et in caelum eam deferam, ubi nunquam penitus tribulationem vel angustiam habebit ».” (Ps. JosÉ DE ARIMATEA, II: 641-642).

183 Ps. JuAn el TeÓlogo, XXXVIII: 593.

184 "El Señor se dirigió entonces a su madre y le dijo: « María ». Ella respondió: « Aquí me tienes, Señor ». El le dijo: « No te aflijas; alégrese más bien y gócese tu corazón, pues has encontrado gracia para poder contemplar la gloria que me ha sido dada por mi Padre ». La santa madre de Dios elevó entonces sus ojos y vio en El una gloria tal, que es inefable a la boca del hombre e incomprensible." (Ps. Juan el TeÓlogo, XXXIV: 591).

185 "El Señor permaneció a su lado y continuó diciendo: « He aquí que desde este momento tu cuerpo va a ser trasladado al paraíso, mientras que tu santa alma va a estar en los cielos, entre los tesoros de mi Padre, [coronada] de un extraordinario resplandor, donde [hay] paz y alegría [propia] de santos ángeles y más aún »." (Ps. JuAn el Teólogo, XXXIV: 591).

186 Ps. Juan el Teólogo, XLIV: 596.

187 "Mas El tomó su alma y la puso en manos de Miguel, no sin antes haberla envuelto en unos como velos, cuyo resplandor es imposible describir." (JuAn DE TESALÓNICA, XII: 631).

188 "Y mientras [al morir María] los ángeles entonaban el pasaje aquel del Cantar de los Cantares en que dice el Señor: « Como el lirio entre espinas, así mi amiga entre las hijas », sobrevino tal resplandor y un perfume tan suave, que todos los circunstantes cayeron sobre sus rostros (de la misma manera que 
Aun representando todas ellas de modo claro y explícito el instante central de la dormición y la acogida del alma de María en el paraíso, dos de las obras aquí analizadas sugieren además el ulterior proceso de su entierro en cortejo fúnebre. En las Koimesis de la Yilanli kilise y de la Panagia Mavriotissa de Kastoria tal sugerencia se expresa por la presencia del profanador judío Jefonías ${ }^{189}$ junto a la litera/féretro de la Virgen, así como, en el fresco de Kastoria, mediante el complementario ángel castigador blandiendo la espada. Tales personajes y detalles iconográficos traducen visualmente las concordancias esenciales entre los tres apócrifos, cuyo contenido medular expresa así el Ps. Juan el Teólogo:

En esto, he aquí que, durante la marcha [del cortejo fúnebre], cierto judío llamado Jefonías, robusto de cuerpo, la emprendió impetuosamente contra el féretro que llevaban los apóstoles. Mas de pronto un ángel del Señor, con fuerza invisible, separó, sirviéndose de una espada de fuego, las dos manos de sus respectivos hombros y las dejó colgadas en el aire a los lados del féretro. ${ }^{190}$

Como no podía menos de esperarse en leyendas tan increíbles, ese fabuloso episodio del intento de profanación concluye en un final feliz con la curación milagrosa de los brazos cortados, tras convertirse el sacrílego judío al cristianismo, ${ }^{191}$ después de reconocer y proclamar las alabanzas de María y Jesús. ${ }^{192}$

cayeron los apóstoles cuando Cristo se transfiguró en su presencia en el Tabor), y durante hora y media ninguno fue capaz de incorporarse." (Ps. José De Arimatea, XI: 647).

${ }^{189}$ El profanador judío, que, según el Ps. Juan el Teólogo, se llama Jefonías, en el relato de Juan de Tesalónica (XIII: 634) es un pontífice sin nombre, mientras en el del Ps. JosÉ DE ARIMATEA (XIV: 648) recibe el nombre de Rubén.

190 Ps. JuAn el Teólogo, XLVI: 597. Como ya apuntamos, este episodio del profanador es también relatado (aunque con variantes poco significativas), por JuAN DE TESALÓNICA (XIII: 633-637) y el Ps. JosÉ de Arimatea (XIV-XVI: 648-649).

${ }^{191}$ En palabras del Ps. José de Arimatea: "Entonces los apóstoles, consternados por claridad tan grande, se levantaron al compás de la salmodia y dio comienzo el traslado del santo cadáver desde el monte de Sión hasta el valle de Josafat. Pero, al llegar a la mitad del camino, he aquí que cierto judío por nombre Rubén les salió al paso, pretendiendo echar al suelo el féretro juntamente con el cadáver de la bienaventurada [virgen] María. Mas de pronto sus manos vinieron a quedar secas hasta el codo, $\mathrm{y}$, de grado o por fuerza, hubo de bajar hasta el valle de Josafat llorando y sollozando al ver que sus manos habían quedado rígidas y adheridas al féretro y que no era capaz de atraerlas de nuevo hacia sí. Después rogó a los apóstoles que le obtuvieran por sus oraciones la salud y el hacerse cristiano. Ellos entonces doblaron sus rodillas y rogaron al Señor que le librase. En aquel mismo momento consiguió, en efecto, la curación y se puso a dar gracias a Dios y a besar las plantas de la Reina y de todos los santos y apóstoles. Inmediatamente fue bautizado en aquel lugar y comenzó a predicar el nombre de Nuestro Señor Jesucristo.” (Ps. JosÉ DE ARIMATEA, XIV-XV: 648-649).

192 Así lo afirma el primer apócrifo: "Al obrarse este milagro, exclamó a grandes voces todo el pueblo de los judíos, que lo había visto: « Realmente es Dios el hijo que diste a luz, joh madre de Dios y siempre virgen María! » Y Jefonías mismo, intimado por Pedro para que declarara las maravillas del Señor, se levantó detrás del féretro y se puso a gritar: « Santa María, tú que engendraste a Cristo Dios, ten compasión de mi ». Pedro entonces se dirigió a él y le dijo: «En nombre de su Hijo, júntense las manos que han sido separadas de ti $»$. Y, nada más decir esto, las manos que estaban colgadas del féretro donde yacía la Señora, se separaron y se unieron de nuevo a Jefonías. Y con esto creyó él mismo y alabó a Cristo Dios, que fue engendrado por ella.” (Ps. Juan el Teólogo, XLVII: 598). Con ligeras variantes el episodio es recogido también por los otros dos apócrifos. Según Juan de Tesalónica, los judíos que se 


\section{Conclusiones}

Al término de esta ya larga serie de análisis iconográficos, algunas conclusiones substanciales se imponen:

En primer lugar, todas las imágenes bizantinas y occidentales de la Dormición de María aquí estudiadas reflejan en mayor o menor medida los principales personajes, episodios, circunstancias y pormenores descritos por los tres textos apócrifos bajo escrutinio.

Ahora bien, ante la imposibilidad de ilustrar todos y cada uno de los innumerables detalles imaginados por tales leyendas, los autores intelectuales y materiales de esas obras de arte optan por elegir los indispensables y, en todo caso, los de más fácil representación visual.

Por otra parte, la composición plástica mediante la cual se traducen los eventos narrados en esos cuentos anónimos adopta una complejidad variable, dependiendo de la técnica y del período histórico: cuanto más determinante y coercitivo es el soporte (marfil, esteatita, tabla, pergamino) y más antigua es la obra (siglos X-XI), tanto más simples son la estructura compositiva y el desarrollo narrativo; por el contrario, cuanto mayor es la amplitud y la libertad que ofrece el soporte (fresco, mosaico, relieve arquitectónico) y más avanzado es el tiempo (siglo XII) tanto más compleja es la composición y tanto más prolija en detalles es la secuencia narrativa.

Semejante relación entre lo simple y lo complejo varía también de modo considerable en dependencia del ámbito territorial donde se producen las obras de arte: a la complejidad compositiva, la exuberancia descriptiva y la elocuencia conceptual características de las Koimesis bizantinas se contraponen la simplicidad estructural, la concisión narrativa y la austeridad eidética típicas de las Dormiciones occidentales.

Apreciable es asimismo la diferencia entre bizantinos y occidentales a la hora de medir el interés por el tema iconográfico del tránsito de la Virgen: mientras los greco-orientales muestran un evidente entusiasmo al concebir, producir, difundir y consumir desde fecha relativamente temprana (desde al menos el siglo X, y, según algunos, desde el propio siglo IX) esas innumerables imágenes de la Koimesis, que vienen a ilustrar plásticamente una de sus más entrañables grandes fiestas litúrgicas, los occidentales, por el contrario, exhiben cierta frialdad y distancia afectiva frente a este motivo iconográfico/doctrinal, cuando, al producir sus esporádicas Dormiciones, se inspiran de manera mecánica en los modelos bizantinos, a los que despojan de muchos ingredientes esenciales, hasta conseguir unas "reinterpretaciones" empobrecidas, de escaso fervor religioso.

Por último, todas esas múltiples diferencias en el tratamiento del motivo iconográfico de la Dormición de María permiten vislumbrar, a la postre, la distinta men-

disponían a matar a los apóstoles en el momento de trasladar el cuerpo de María hacia el sepulcro fueron cegados por los ángeles, salvo cierto pontífice (cuyo nombre no menciona), quien se abalanzó sobre el féretro, con la intención de arrojarlo al suelo. Pero sus manos quedaron adheridas al féretro, después de ser desprendidas de su tronco a la altura de los codos. Al suplicar entre lágrimas a los apóstoles que tuviesen piedad de él, Pedro le prometió la curación de sus brazos, si creía en Cristo y en María. El milagro de la curación la obtuvo el pontífice después de bendecir y proclamar loas a la Virgen durante tres horas. (JuAn DE TESALÓNICA, XIII: 633-637). 
talidad y espiritualidad de los bizantinos y los occidentales de los siglos X-XII: si los primeros parecen buscar una religiosidad imbuida por la devoción, la fe ciega y el simbolismo, los occidentales, en cambio, parecerían querer vivir su religión con cierto distanciamiento y con una racionalidad más fría y objetiva.

\section{Fuentes}

Alvarez Campos, Sergio (comp.), 1981 Corpus Marianum Patristicum, vol. V, Burgos, Aldecoa.

Aranda Pérez, Gonzalo, 1995 Dormición de la Virgen. Relatos de la tradición copta, Madrid, Editorial Ciudad Nueva/Fundación San Justino, Col. Apócrifos Cristianos, $2,324 \mathrm{p}$.

Damasceno, Juan (Santo), 1961 Saint Jean Damascène, Homélies sur la Nativité et la Dormition (Texte grec, introduction, traduction et notes par Pierre Voulet), Paris, Les Éditions du Cerf, Coll. Sources Chrétiennes, p. 171-173.

GonzÁlez CASADO, Pilar, 2002 La dormición de la Virgen. Cinco relatos árabes, Madrid, Trotta, $218 \mathrm{p}$.

Jacobo de Sarug, 451-521 Homilia de sancta Dei Matris Dormitione et sepultura. En: Sergio Alvarez Campos (comp.), Corpus Marianum Patristicum, vol. V, Burgos, Aldecoa, 1981, p. 96

Juan de Tesalónica, Dormición de Nuestra Señora, Madre de Dios y siempre Virgen María. En SANTos Otero 2006: 605-639.

Pseudo José de Arimatea, De transitu Beatae Mariae Virginis (auctore Pseudo-Josepho ab Arimathea). En Santos Otero 2006: 640-653.

Pseudo Juan el Teólogo, Tratado de San Juan el Teólogo sobre la dormición de la Santa Madre de Dios. En Santos Otero 2006: 576-600.

Santos Otero, Aurelio de, 2006 Los evangelios apócrifos, Salamanca: La Editorial Católica, Col. Biblioteca de Autores Cristianos, 148, 705 p.

\section{Bibliografía}

BAngo Torviso, Isidro G., 2003 El románico. Arte de la Alta Edad Media, Vol. 3 de Historia Universal del Arte (Dir. Juan José Junquera), Madrid, Espasa, 432 p.

Coche de la Ferté, Étienne, 1981 L'art de Byzance, Paris, Mazenod, 1981, 591 p.

Connor Carolyn L., 1991 Art and miracles in Medieval Byzantium. The crypt of Hosios Loukas and its frescoes, Princeton, NJ, Princeton University Press, 1991, 132 pp. + il. s.p.

Demus, Otto, 1970 Byzantine art and the West (The Wrightsman Lectures III), London, Weidenfeld and Nicolson, 1970, xxi $+274 \mathrm{p}$. 
Dient, Charles, 1926 Manuel d'art byzantin, Paris, A. \& J. Picard, 1925 (2e édition revue et augmentée), $2 \mathrm{v}$.

Evans, Helen C. y Wixom, William D. (eds.), 1997 The glory of Byzantium. Art and culture in the Middle Byzantine Era A.D. 843-1261, New York, Metropolitan Museum of Art, New York, 1997, 574 p.

Guillou, André, 1974 La civilisation byzantine, Paris, Arthaud, Coll. Les Grandes Civilisations, $619 \mathrm{p}$.

Jolivet-LÉvy, Catherine, 1991 Les églises byzantines de Cappadoce. Le programme iconographique de l'abside et de ses abords, Paris, Editions du CNRS, 392 p. + $185 \mathrm{pl}$.

Kostof, Spiro, 1972 Caves of God. The monastic environment of Byzantine Cappadocia, Cambridge, Mass / London, The MIT Press, 296 p.

LAZAREV, Viktor, 1966 Old Russian murals \& mosaics from the XI to the XVI century, London, Phaidon, 290 p. + il.

LAZAREV, Viktor, 1967 Storia della pittura bizantina (Edizione italiana rielaborata e ampliata dall'autore), Torino, Einaudi, Coll. Biblioteca di storia dell'arte, 7, 1967, XLI, $497 \mathrm{p}$.

Lafontaine-Dosogne, Jacqueline, 1987 Histoire de l'art byzantin et chrétien d'Orient, Louvain-la-Neuve, Université Catholique de Louvain, 1987, 287 p., + lam. s.p.

MaguiRe, Henry, 1996 The icons of their bodies. Saints and their images in Byzantium, Princeton, NJ, Princeton University Press, $222 \mathrm{p}$.

Nieto, Benedicto, 1950 La Asunción de la Virgen en el arte. Vida de un tema iconográfico, Madrid, Afrodisio Aguado, 1950, 197 p. + pl. s.p.

SCHILLER, Gertrud, 1980 Ikonographie der christlichen Kunst. Band 4,2, Maria, Gütersloh, Gütersloher VerlagHaus, 1980, 472 p.

SchUG-WiLle, Christa, 1969 Art of the Byzantine world, New York, Harry N. Abrams, $1969,262 \mathrm{p}$.

Stern, Henri, 1966 L'art byzantin, Paris, Press Universitaires de France, Coll. Les Neuf Muses, 1966, 186 pp.

StiERlin, Henri, 1988 Orient byzantin. De Constantinople à l'Arménie et de Syrie en Éthiopie, Fribourg, Seuil, Office du Livre, 1988, 232 p.

Tацвот Rice, David, 1968 Byzantine art (Revised and expanded edition), Harmondsworth, Penguin Books, Coll. Pelican books, 1968 [1935], 580 p.

THÉREL, Marie-Louise, 1984 Le triomphe de la Vierge-Église. Sources historiques, littéraires et iconographiques, Paris, Éditions du CNRS, 1984, 374 p.

THIERry, Nicole y Michel, 1963 Nouvelles églises rupestres de Cappadoce, Région du Hasan Dagin (Avant-propos par André Grabar), Paris, Klincksieck, 1963, 248 p. + il., s.p.

Thierry, Nicole, 1983 Haut Moyen-Âge en Cappadoce, Les églises de la région de Çavusin, Tome I, Paris, Librairie Orientaliste Paul Geuthner, 197 p. + il., s.p. 
Toscano, Giuseppe M., 1960 Il pensiero cristiano nell'arte, Bergamo, Istituto Italiano d'Arti Grafiche, 1960,3 v.

Wharton, Annabel Jane, 1988 Art of empire. Painting and architecture of the Byzantine periphery. A comparative study of four provinces, University Park; London, Pennsylvania State University Press, 1988, xvi, 198 p.

Weitzmann, Kurt, 1968 Weitzmann, Kurt, Chatzidakis, Manolis, Miatev, Krsto y RAdojcic, Svetozar, Icons from South Eastern Europe and Sinai, London, Thames and Hudson, $220 \mathrm{p}$. + varias paginaciones en $\mathrm{n}^{\mathrm{o}}$ romanos

Weitzmann, Kurt, 1980a Byzantine Liturgical Psalters and Gospels, London, Variorum Reprints, paginación irregular

Weitzmann, Kurt, 1980b Weitzmann, Kurt, Chatzidakis, Manolis y Radojcic, Svetozar, Icons, New York, Alpine Fine Arts, 1980, 239 p.

Weitzmann, Kurt, 1980c Weitzmann, Kurt, "Sinai. Icon painting from the Sixth to the Eight century", En: Weitzmann, Kurt, Manolis Chatzidakis y Svetozar RadoJCIC 1980b, p. 11-60. 